\title{
Formulary Review of 2 New Biologic Agents: Tocilizumab for Rheumatoid Arthritis and Ustekinumab for Plaque Psoriasis
}

\author{
Jeremy A. Schafer, PharmD; Nicole K. Kjesbo, PharmD, BCPS; \\ and Patrick P. Gleason, PharmD, BCPS, FCCP
}

\begin{abstract}
BACKGROUND: Two autoimmune biologics were recently approved by the FDA: ustekinumab in September 2009 for the treatment of moderate to severe plaque psoriasis in adults who are candidates for phototherapy or systemic therapy and tocilizumab in January 2010 for adult patients with moderate to severe rheumatoid arthritis (RA) who have not responded adequately to 1 or more tumor necrosis factor (TNF) antagonist therapies. Both agents use new mechanisms of action and add to the growing group of autoimmune biologics.
\end{abstract}

OBJECTIVE: To critically review the phase 3 trials for ustekinumab and tocilizumab and provide managed care considerations in the context of the 9 other biologic agents on the market in the United States that are used to treat moderate to severe RA or psoriasis.

METHODS: A MEDLINE review was performed for articles published and available through January 2010 using keywords "ustekinumab" and "tocilizumab" with an emphasis on phase 3 trials. The literature search was limited to articles in English, clinical trials, randomized controlled trials, and research conducted in humans. Search results for ustekinumab included 8 articles of which 4 were excluded for not being psoriasis or psoriatic arthritis trials. Search results for tocilizumab included 16 articles of which 8 were excluded for not being RA trials or using biomarkers as primary endpoints. Additional information was obtained from the FDA website.

RESULTS: Three phase 3 trials are available for ustekinumab. Ustekinumab demonstrated superior efficacy to placebo in 2 trials for the treatment of psoriasis. In a 12-week trial, ustekinumab 45 milligrams $(\mathrm{mg})$ and $90 \mathrm{mg}$ demonstrated significantly higher rates of $75 \%$ improvement in the psoriasis area and severity index (PASI 75$)(67.5 \%$ and $73.8 \%$, respectively) compared with etanercept $(56.8 \%)$ in the first phase 3 comparative psoriasis trial between autoimmune biologics ( $P<0.05$ for both comparisons). In a phase 3 trial of RA patients who had failed prior TNF antagonist therapy, a $20 \%$ improvement in signs or symptoms according to the American College of Rheumatology criteria (ACR 20) at week 24 was achieved by significantly more study participants in the tocilizumab $8 \mathrm{mg}$ per kilogram $(\mathrm{kg})$ $(50.0 \%)$ and $4 \mathrm{mg}$ per $\mathrm{kg}(30.4 \%)$ groups than the placebo group $(10.1 \%$, $P<0.001$ for both tocilizumab groups compared with placebo). Safety data for ustekinumab are limited to use for less than 2 years, and the prescribing information contains warnings regarding infection and malignancy. Tocilizumab is associated with neutropenia, thrombocytopenia, and elevations in lipids and liver function tests. Tocilizumab has unique adverse events when compared with other autoimmune biologics and requires laboratory testing and careful monitoring.

CONCLUSIONS: Ustekinumab and tocilizumab are new additions to the treatment of autoinflammatory disease. The majority of safety data for both agents are from trials lasting 3 to 6 months. Published long-term safety data for tocilizumab are limited to less than 143 patients treated longer than 5 years, and safety data for ustekinumab are scant beyond 2 years of use; therefore, clinicians should exercise caution prior to widespread adoption. The comparative efficacy and safety trial of etanercept and ustekinumab brings important clinical information to decision makers. Tocilizumab is indicated after failure or intolerance to a TNF antagonist and has unique safety concerns. Managed care plans will consider the experience and long-term data of these agents along with efficacy data and cost when establishing management programs such as prior authorization or step therapy.

\section{J Manag Care Pharm. 2010;16(6):402-16}

Copyright $\odot 2010$, Academy of Managed Care Pharmacy. All rights reserved.

\section{What is already known about this subject}

- Biologics are an important component in the management of moderate to severe rheumatoid arthritis (RA) and psoriasis.

- Tumor necrosis factor (TNF) antagonists have been found to be effective in multiple autoinflammatory diseases including RA, psoriasis, Crohn's disease, and ulcerative colitis. However, patients may not experience adequate response with a TNF antagonist or lose the therapeutic response. New agents with different mechanisms of action are needed.

\section{What this study adds}

- Ustekinumab demonstrated superior efficacy to etanercept in an investigator-blinded, phase 3 psoriasis trial. The FDA-approved indication for tocilizumab is supported by clinical data demonstrating efficacy in RA patients who had failed 1 or more TNF antagonists.

- Long-term safety data are limited for ustekinumab and tocilizumab. Both agents increase the risk of infection, and tocilizumab has adverse effects on neutrophils, platelets, lipids, and liver enzymes.

- How ustekinumab and tocilizumab will be used in clinical practice is unclear at this time. More data and experience are needed. Cost continues to be an issue with autoimmune biologics, with increases in population-level expenditures due to the combination of higher utilization and price inflation.

- Ustekinumab has higher drug cost at initiation of therapy because 2 doses are administered in the first 30 days at weeks 0 and 4 , a current (2010) average wholesale price (AWP) of $\$ 11,912$, and $\$ 5,596$ every 12 weeks thereafter, yielding an annual drug cost of approximately $\$ 33,576$ in the first year for 6 doses and $\$ 22,384$ annually thereafter for 4 doses per year. The cost of tocilizumab depends on body weight, with dosing every 4 weeks at either 4 $\mathrm{mg}$ or $8 \mathrm{mg}$ per $\mathrm{kg}$. The initial dose is $4 \mathrm{mg}$ per $\mathrm{kg}$. Annual tocilizumab drug cost in a $70 \mathrm{~kg}$ person ranges from $\$ 13,368$ at $4 \mathrm{mg}$ per $\mathrm{kg}$ to $\$ 26,748$ at $8 \mathrm{mg}$ per $\mathrm{kg}$ at 12 doses per year. 
$\mathrm{R}$ heumatoid arthritis (RA) is an autoimmune, chronic, multisystem, inflammatory joint disease characterized by synovitis, pain, and fatigue. RA affects an estimated 1.3 million American adults aged 18 years or older, or $0.6 \%$ of the population of the United States. ${ }^{1}$ The costs of RA to society and individuals are considerable. The estimated annual cost of RA in the United States is between $\$ 26$ and $\$ 32.4$ billion. $^{2}$ An analysis of studies on the cost of RA estimated the annual mean direct cost of RA per patient to be $\$ 5,425$ with annual indirect costs of $\$ 9,744$ (1998 dollars). ${ }^{2}$ RA patients with concomitant cardiovascular disease or depression have even higher costs, more medication use, and more hospitalizations compared with patients with RA only. ${ }^{3}$ Patients with RA progressively accumulate disability leading to unemployment and increasing health care utilization. ${ }^{3-5}$

Psoriasis is a common chronic autoimmune condition that is characterized by red, scaly, and indurated skin lesions. ${ }^{6}$ These lesions more commonly occur on the scalp, elbows, umbilicus, gluteal cleft, genital areas, and knees. Symptoms usually include itching, burning, and soreness of the lesions as well as joint pains or true arthritis. The exact cause of psoriasis is unknown. Psoriasis affects between $1 \%$ and $3 \%$ of the U.S. population, an estimated 4.5-7.5 million Americans. ${ }^{7}$ Of these persons, approximately one-third suffer from moderate to severe disease that can not be controlled by topical therapies. ${ }^{8}$ Total direct and indirect health care costs of psoriasis are calculated at $\$ 11.25$ billion annually in the United States. ${ }^{9}$ Loss of work accounts for $40 \%$ of the cost burden. ${ }^{9}$

Biologics are therapeutic agents derived from human or animal sources or manufactured using recombinant deoxyribonucleic acid (DNA) technology. Biologics may be proteins, monoclonal antibodies, recombinant receptors, or complex sugars. Biologics are used in a variety of disease states including autoimmune disease. The introduction of the autoimmune biologics has had a significant impact on the management of autoinflammatory diseases. Guidelines have predominantly placed biologic treatments as second line behind conventional therapy for RA and psoriasis. The American College of Rheumatology 2008 guidelines recommend methotrexate as first-line therapy to be followed by a tumor necrosis factor (TNF) antagonist if the response to methotrexate is inadequate. ${ }^{10}$ Similar recommendations can be found in other guidance including the National Institute for Health and Clinical Excellence (NICE) technology appraisal no. 130 (October 2007). ${ }^{11}$ American Academy of Dermatology guidelines recommend topical therapies for patients with limited disease. ${ }^{12}$ Biologics are an option along with ultraviolet light $\mathrm{A}$ or B/psoralen (UVB/PUVA) or other systemic therapies (acretin, methotrexate) for psoriasis patients with extensive disease or those with local disease who fail topical therapy. ${ }^{12}$

There is a significant amount of clinical data on the use of biologics in autoinflammatory diseases, but questions remain on management of treatment failures and comparative efficacy. A United Kingdom (UK) database study found, in a registry of 6,739 patients with RA, that a total of 856 patients (12.7\%) switched to a second TNF due to lack of efficacy or intolerance. ${ }^{13}$ Patients who switched due to lack of efficacy $(n=503)$ were more likely to fail a second TNF (hazard ratio $[\mathrm{HR}]=2.7$, 95\% confidence interval $[\mathrm{CI}]=2.1-3.4){ }^{13}$ Additional studies have found that patients switching from 1 TNF antagonist to another have a progressively smaller chance of treatment success with each switch. ${ }^{14}$ Choice of autoimmune biologic is limited by the lack of comparative data between different agents. A 2007 report sponsored by the Agency for Healthcare Research and Quality stated that there is an urgent need for comparative data for the autoimmune biologics. ${ }^{15}$

Ustekinumab, approved by the U.S. Food and Drug Administration (FDA) in September 2009, and tocilizumab, approved in January 2010, are autoimmune biologics indicated for the treatment of psoriasis and RA, respectively (Table 1). ${ }^{16-19}$ Both agents have distinct mechanisms of action that differ from those of previously available autoimmune biologics. Tocilizumab has demonstrated efficacy in patients failing at least 1 TNF antagonist, and the product label specifies use in "adult patients with moderately to severely active rheumatoid arthritis who have had an inadequate response to one or more TNF therapies."17 Ustekinumab has been compared with etanercept in the first phase 3, double-blind, trial to compare autoimmune biologics. ${ }^{20}$ Ustekinumab is approved for use in "the treatment of adult patients (18 years or older) with moderate to severe plaque psoriasis who are candidates for phototherapy or systemic therapy."16

The purpose of this review is to provide a summary of the clinical data for ustekinumab and tocilizumab with an emphasis on the phase 3 clinical trials. Issues with the autoimmune biologics are discussed in a managed care context, and insight is provided for formulary decision makers on management options.

\section{Methods}

A MEDLINE review was performed for articles published and available through January 2010, using keywords "ustekinumab" and "tocilizumab" with an emphasis on published, randomized, controlled trials (Figure 1). The literature search was limited to articles in English, clinical trials, randomized controlled trials, and research conducted in humans. Articles that were review articles, meta-analyses, or not clinical trials were excluded. Articles for disease states other than RA and psoriasis were also excluded. Search results for ustekinumab included 8 articles of which 4 were excluded for not being psoriasis or psoriatic arthritis trials. Search results for tocilizumab included 16 articles of which 8 were excluded for not being RA trials or using biomarkers as primary endpoints. Additional information was obtained from the FDA website. 
Formulary Review of 2 New Biologic Agents: Tocilizumab for Rheumatoid Arthritis and Ustekinumab for Plaque Psoriasis

TABLE 1 Approved Biologic Treatments ${ }^{\mathrm{a}}$ for Autoinflammatory Diseases

\begin{tabular}{|c|c|c|c|c|c|c|c|c|c|}
\hline Drug & Mechanism of Action & \begin{tabular}{c|} 
Route of \\
Administration \\
\end{tabular} & RA & $\begin{array}{l}\text { Juvenile } \\
\text { RA }\end{array}$ & $\begin{array}{l}\text { Psoriatic } \\
\text { Arthritis }\end{array}$ & AS & Psoriasis & UC & CD \\
\hline Adalimumab (Humira) 47 & TNF antagonist & subcutaneous & $\sqrt{ }$ & $\sqrt{ }$ & $\sqrt{ }$ & $\sqrt{ }$ & $\sqrt{ }$ & & $\sqrt{ }$ \\
\hline Etanercept (Enbrel)46 & TNF antagonist & subcutaneous & $\sqrt{ }$ & $\sqrt{ }$ & $\sqrt{ }$ & $\sqrt{ }$ & $\sqrt{ }$ & & \\
\hline Infliximab (Remicade) ${ }^{38}$ & TNF antagonist & IV infusion & $\sqrt{ }$ & & $\sqrt{ }$ & $\sqrt{ }$ & $\sqrt{ }$ & $\sqrt{ }$ & $\sqrt{ }$ \\
\hline Certolizumab (Cimzia) 48 & TNF antagonist & subcutaneous & $\sqrt{ }$ & & & & & & $\sqrt{ }$ \\
\hline Alefacept (Amevive) ${ }^{49}$ & Reduce T helper cell & subcutaneous & & & & & $\sqrt{ }$ & & \\
\hline Anakinra (Kineret) ${ }^{50}$ & IL-1 receptor antagonist & subcutaneous & $\sqrt{ }$ & & & & & & \\
\hline Abatacept (Orencia) ${ }^{53}$ & $\begin{array}{c}\text { Blocks CD28, inhibiting } \\
\mathrm{T} \text { cell activation }\end{array}$ & IV infusion & $\sqrt{ }$ & $\sqrt{ }$ & & & & & \\
\hline Rituximab (Rituxan) ${ }^{51}$ & $\begin{array}{l}\text { Binds CD20 receptor and } \\
\text { reduces B cell count }\end{array}$ & IV infusion & $\sqrt{\mathrm{b}}$ & & & & & & \\
\hline Golimumab (Simponi) $^{52}$ & TNF antagonist & subcutaneous & $\sqrt{ }$ & & $\sqrt{ }$ & $\sqrt{ }$ & & & \\
\hline 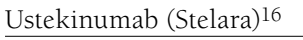 & IL-12 and 23 antagonist & subcutaneous & & & & & $\sqrt{ }$ & & \\
\hline Tocilizumab (Actemra) ${ }^{17}$ & IL-6 receptor antagonist & IV infusion & $\sqrt{b}$ & & & & & & \\
\hline
\end{tabular}

\section{Results}

\section{Pharmacology}

Ustekinumab. Interleukin (IL) IL-12 and IL-23 are involved in innate and adaptive immune response and have been implicated in the pathogenesis of psoriasis. IL-12 stimulates T-helper (TH)1 cell immune responses leading to the secretion of interferon and T cell recruitment. IL-23 induces IL-17, regulates $\mathrm{T}$ memory cells, and activates macrophages to maintain chronic autoimmune inflammation. ${ }^{21}$ Ustekinumab is a fully human immunoglobin (Ig)Gl antibody that binds to the p40 subunit of IL-12 and IL-23 (Figure 2). The binding prevents interaction with the IL-12R beta 1 receptor, neutralizing IL-12 and IL-23 mediated cell immune responses. ${ }^{22}$

Tocilizumab. IL- 6 acts as a stimulator of B and T cell functions, including promoting the differentiation of $\mathrm{B}$ cells into antibody producing plasma cells. ${ }^{23,24}$ IL-6, when bound to the soluble IL-6 receptor, has been shown to activate chemokine production and up regulate expression of adhesion molecules, leading to recruitment of leukocytes at inflammatory sites..$^{23,24}$ These actions have implicated IL- 6 as an important component of inflammatory diseases including RA. High levels of IL-6 have been found in the serum and joints of RA patients. ${ }^{23,24}$ Additionally, IL- 6 has been shown to induce proliferation of osteoclasts, which may be a component of the bone degradation seen in RA. ${ }^{23,24}$ Tocilizumab is a humanized, monoclonal antibody that can bind to both membranous and soluble IL- 6 receptors (Figure 2). The blockade prevents the interaction of IL- 6 and IL- 6 receptor, interrupting the actions of IL- 6 that contribute to the disease processes in RA. ${ }^{24}$

\section{Efficacy}

PHOENIX 1: Ustekinumab in psoriasis patients eligible for systemic treatment. The efficacy of ustekinumab in the treatment of patients with moderate to severe psoriasis was assessed in the "PHOENIX 1" study, a phase 3, double-blind, placebo-controlled, randomized trial (Table 2). ${ }^{25}$ Patients eligible for enrollment were at least 18 years of age, had a diagnosis of psoriasis for at least 6 months with at least $10 \%$ of the body surface affected, and were candidates for systemic or phototherapy. Exclusion criteria included nonplaque forms of psoriasis, history or symptoms of active tuberculosis, a recent serious systemic or local infection, malignancy, treatment with any agent that specifically targeted IL-12 or IL-23, treatment with a biological or investigational agent received in previous 3 months, treatment with conventional systemic psoriasis therapy or phototherapy received within the previous 4 weeks, or a topical psoriasis treatment received within the previous 2 weeks.

The trial had 3 phases: a placebo-controlled phase between weeks $0-12$, a placebo cross-over and active treatment phase from weeks 12-40, and a randomized withdrawal phase between weeks 40-76. Patients were randomized to subcutaneous injections of ustekinumab 45 milligrams ( $m$; $n=255$; mean age 44.8 years, $68.6 \%$ male), $90 \mathrm{mg}(n=256$; mean age 46.2 years, $67.6 \%$ male), or placebo $(n=255$; mean age 44.8 years, $71.8 \%$ male) at weeks 0,4 , and every 12 weeks thereafter. The primary endpoint was achievement of a $75 \%$ improvement in the psoriasis area and severity index (PASI 75) at week 12. Secondary endpoints included the proportion of patients achieving a clear or minimal physician's global assessment (PGA) score at week 12, and the time to loss of PASI 75 during the withdrawal phase. 


\section{FIGURE 1 Flowchart of Literature Selection}

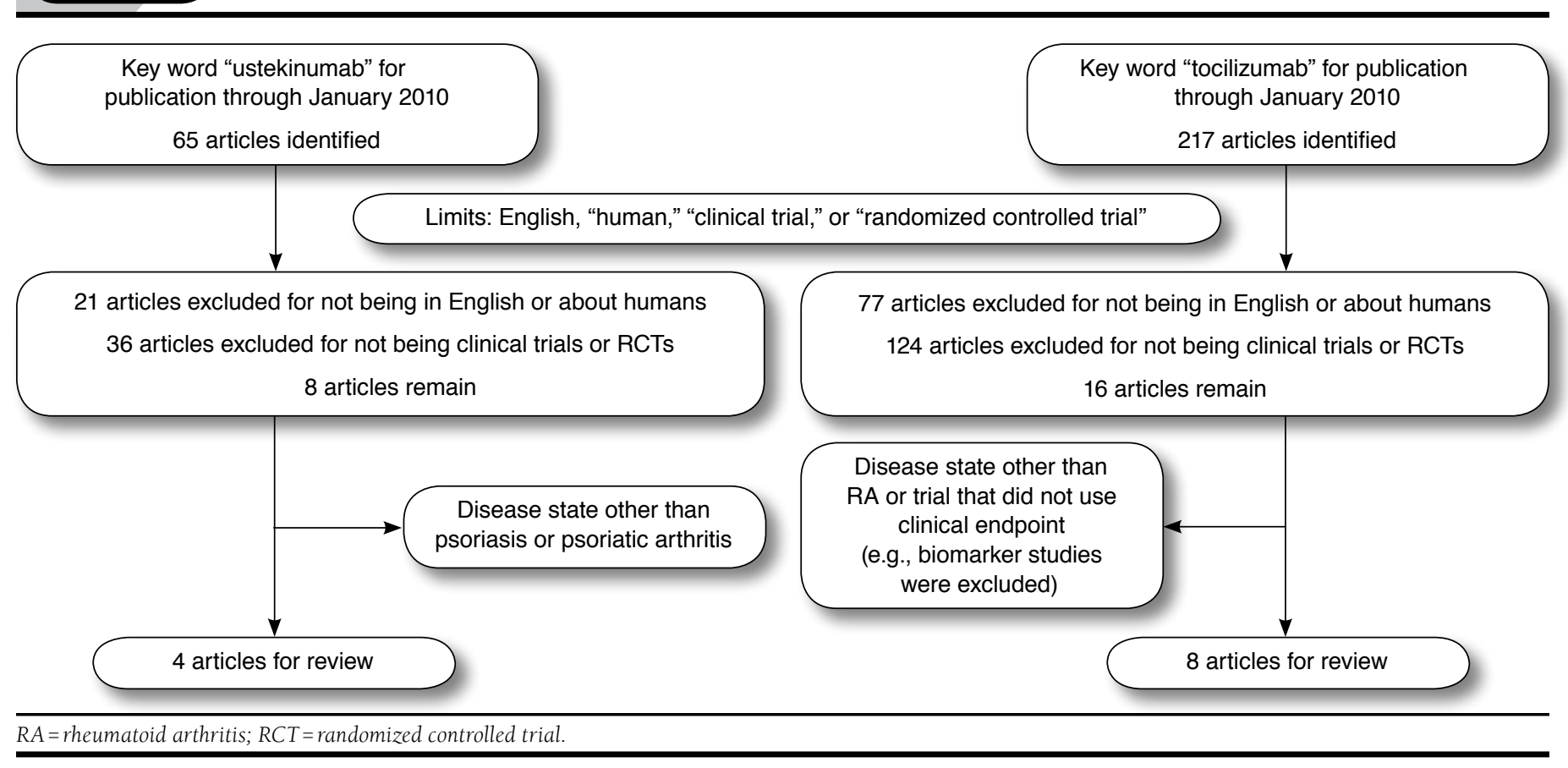

\begin{tabular}{|c|c|c|}
\hline \multicolumn{3}{|c|}{ PHOENIX $1^{25}$} \\
\hline Drug & $\begin{array}{l}\text { PASI } 75 \text { Response } \\
\text { at Week } 12(\%)\end{array}$ & $\begin{array}{c}P \text { Value Compared } \\
\text { with Placebo }\end{array}$ \\
\hline Ustekinumab 45 mg $(n=255)$ & 67.1 & $<0.001$ \\
\hline Ustekinumab $90 \mathrm{mg}(\mathrm{n}=256)$ & 66.4 & $<0.001$ \\
\hline Placebo $(n=255)$ & 3.1 & - \\
\hline \multicolumn{3}{|c|}{ PHOENIX $2^{26}$} \\
\hline Drug & $\begin{array}{l}\text { PASI } 75 \text { Response } \\
\text { at Week } 12(\%)\end{array}$ & $\begin{array}{l}P \text { Value Compared } \\
\text { with Placebo }\end{array}$ \\
\hline Ustekinumab $45 \mathrm{mg}(\mathrm{n}=409)$ & 66.7 & $<0.001$ \\
\hline Ustekinumab $90 \mathrm{mg}(\mathrm{n}=411)$ & 75.7 & $<0.001$ \\
\hline Placebo $(n=410)$ & 3.7 & - \\
\hline \multicolumn{3}{|c|}{ ACCEPT $^{20}$} \\
\hline Drug & $\begin{array}{l}\text { PASI } 75 \text { Response } \\
\text { at Week } 12(\%)\end{array}$ & $\begin{array}{l}P \text { Value Compared } \\
\text { with Etanercept }\end{array}$ \\
\hline Ustekinumab 45 mg $(n=209)$ & 67.5 & 0.012 \\
\hline Ustekinumab $90 \mathrm{mg}(\mathrm{n}=347)$ & 73.8 & $<0.001$ \\
\hline Etanercept $50 \mathrm{mg}(\mathrm{n}=347)$ & 56.8 & - \\
\hline
\end{tabular}

The study enrolled 766 patients. Baseline demographic and clinical characteristics were similar between treatment groups. Patients had an average 20-year history of psoriasis, and approximately two-thirds of patients in each group were men. Mean involved body surface area (BSA) at baseline was between $25.2 \%$ and $27.7 \%$ for all groups. A total of $55.3 \%$, $55.1 \%$, and $55.7 \%$ in the ustekinumab $45 \mathrm{mg}, 90 \mathrm{mg}$, and placebo groups, respectively, had tried psoralen plus ultraviolet A (PUVA), methotrexate, acitretin, or cyclosporine in the past. A total of $52.5 \%, 50.8 \%$, and $50.2 \%$ in the $45 \mathrm{mg}, 90 \mathrm{mg}$, and placebo groups, respectively, had tried an autoimmune biologic-etanercept, alefacept, efalizumab, infliximab, or adalimumab-prior to study initiation.

A PASI 75 score was achieved by $67.1 \%, 66.4 \%$, and $3.1 \%$ of patients in the ustekinumab $45 \mathrm{mg}, 90 \mathrm{mg}$, and placebo groups, respectively $(P<0.001$ for both strengths compared with placebo) at week 12. A PGA score of clear or minimal was achieved by $60.4 \%, 61.7 \%$, and $3.9 \%$ of patients treated with ustekinumab $45 \mathrm{mg}, 90 \mathrm{mg}$, and placebo, respectively $(P<0.001$ for both strengths compared with placebo), at week 12. Week 28 results demonstrated durable results for ustekinumab with $71.2 \%$ and $78.6 \%$ of patients treated with $45 \mathrm{mg}$ or $90 \mathrm{mg}$ achieving or maintaining a PASI 75 score. Patients moving from placebo to ustekinumab $45 \mathrm{mg}$ or $90 \mathrm{mg}$ had PASI 75 response rates of $65.9 \%$ and $84.9 \%$, respectively, at week 28 . The median time to loss of PASI 75 in patients withdrawn from therapy was 15 weeks. Patients sustained on ustekinumab during the withdrawal phase did not lose response.

PHOENIX 2: Ustekinumab in psoriasis patients eligible for systemic treatment. "PHOENIX 2" compared ustekinumab with placebo for the treatment of moderate to severe psoriasis in a study design similar to PHOENIX 1 (Table 2). ${ }^{26}$ Patients were at least 18 years of age, had a diagnosis of psoriasis for at 


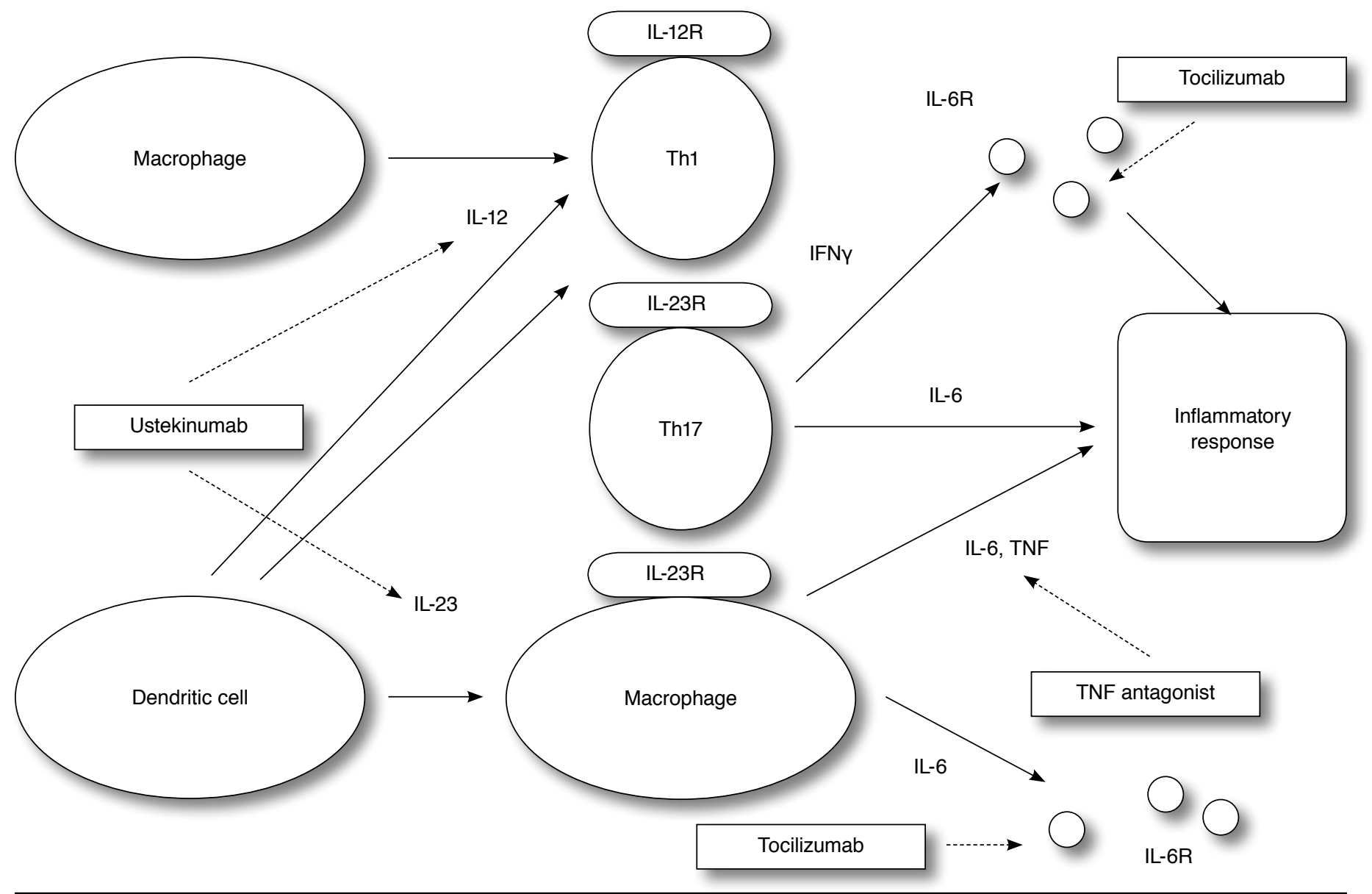

adapted from Iwakura $\mathrm{Y}$ and Ishigame $\mathrm{H}^{54}$ and other references. ${ }^{22,24}$

IFN=interferon; IL= interleukin; $R=$ receptor; $T N F=$ tumor necrosis factor; $T$ h $=T$ helper cell.

least 6 months with at least 10\% of the body surface affected, and were candidates for systemic or phototherapy. Exclusion criteria were similar to criteria used in PHOENIX 1.

The trial had 3 phases: a placebo-controlled phase between weeks $0-12$, a placebo cross-over and active treatment phase from weeks 12 to 28 , and a randomized dose-intensification phase from weeks 28-52. Patients were randomly assigned to subcutaneous ustekinumab $45 \mathrm{mg}(\mathrm{n}=409$; mean age 45.1 years, 69.2\% male), $90 \mathrm{mg}(\mathrm{n}=411$; mean age 46.6 years, $66.7 \%$ male), or placebo ( $n=410$; mean age 47.0 years, $69.0 \%$ male) at weeks 0,4 , and every 12 weeks thereafter. At week 12 , patients treated with placebo were re-randomized to either ustekinumab $45 \mathrm{mg}$ or $90 \mathrm{mg}$ every 12 weeks. At week 28 , patients achieving a partial response (improvement of at least PASI 50 but less than PASI 75) were re-randomized to ustekinumab dosed every 8 or 12 weeks. The primary endpoint was achievement of a PASI 75 score at week 12. Secondary end- points included the proportion of patients achieving a clear or minimal PGA score at week 12, and the proportion of patients achieving a PASI 75 score between weeks 40 and 52 during the dose-intensification phase.

The study enrolled 1,230 patients of whom approximately two-thirds in each group were men. Groups were balanced with regard to demographic and baseline characteristics. Average disease duration of psoriasis was approximately 20 years. Involved BSA at baseline was $25.9 \%, 27.1 \%$, and $26.1 \%$ in the ustekinumab $45 \mathrm{mg}, 90 \mathrm{mg}$, and placebo groups, respectively. A total of $54.5 \%, 54.5 \%$, and $58.8 \%$ in the $45 \mathrm{mg}, 90 \mathrm{mg}$, and placebo groups, respectively, had tried PUVA, methotrexate, acitretin, or cyclosporine prior to study initiation. A total of $38.4 \%, 36.5 \%$, and $38.8 \%$ in the $45 \mathrm{mg}, 90 \mathrm{mg}$, and placebo groups, respectively, had tried an autoimmune biologic-etanercept, alefacept, efalizumab, infliximab, or adalimumabprior to study initiation. 
A PASI 75 score was achieved by $66.7 \%, 75.7 \%$, and $3.7 \%$ of patients in the ustekinumab $45 \mathrm{mg}, 90 \mathrm{mg}$, and placebo groups, respectively, at week $12(P<0.001$ for both ustekinumab regimens compared with placebo). A PGA score of cleared or minimal was achieved by $68 \%, 73.5 \%$, and $4.9 \%$ of patients in the ustekinumab $45 \mathrm{mg}, 90 \mathrm{mg}$, and placebo groups, respectively, at week $12(P<0.001$ for both ustekinumab regimens compared with placebo). At week 28 , the proportions of patients who were partial responders in the ustekinumab $45 \mathrm{mg}$ and 90 mg groups were $22.7 \%$ and $15.8 \%$, respectively. Increasing the dosing frequency to every 8 weeks did not increase the number of visits with a PASI 75 response (1.75 visits in 8-week group vs. 1.56 visits in 12 -week group, $P=0.468$ ).

Analysis of secondary endpoints in the PHOENIX-2 trial determined the effect of ustekinumab on anxiety and depression scales in patients with psoriasis. ${ }^{27}$ The analysis used the Hospital Anxiety and Depression Scale (HADS) to assess patients' mental health in the study. A score of 8 or greater on the HADS scale indicated presence of depression or anxiety, respectively. At baseline, a HADS-Anxiety score of 8 or greater was reported in $38.2 \%, 41.0 \%$, and $41.6 \%$ of patients in the ustekinumab $45 \mathrm{mg}, 90 \mathrm{mg}$, and placebo groups, respectively. A HADS-Depression score of 8 or greater at baseline was reported in $24.7 \%, 31.1 \%$, and $24.2 \%$ of patients in the ustekinumab 45 mg, $90 \mathrm{mg}$, and placebo groups, respectively. At week 12, the proportion of patients reporting a HADS-Anxiety score of 8 or greater was $25.7 \%, 27.1 \%$, and $43.0 \%$ in the ustekinumab 45 $\mathrm{mg}, 90 \mathrm{mg}$, and placebo groups, respectively $(P<0.001$ for both ustekinumab groups compared with placebo). At week 12, the proportion of patients reporting a HADS-Depression score of 8 or greater was $12.8 \%, 12.5 \%$, and $34.4 \%$ in the ustekinumab $45 \mathrm{mg}, 90 \mathrm{mg}$, and placebo groups, respectively $(P<0.001 \mathrm{for}$ both ustekinumab groups compared with placebo). ${ }^{27}$

ACCEPT: Comparative trial of ustekinumab and etanercept. The efficacy of ustekinumab in the treatment of moderate to severe plaque psoriasis was compared with etanercept in a phase 3, investigator-blinded, randomized trial. ${ }^{20}$ Patients who were at least 18 years of age with a diagnosis of plaque psoriasis for at least 6 months with at least $10 \%$ of BSA affected, were candidates for phototherapy or systemic therapy, and had failed to respond to (or were intolerant of) cyclosporine, methotrexate, or PUVA, were eligible to enroll. No previous treatment with ustekinumab or etanercept was allowed. Other exclusion criteria included nonplaque or druginduced forms of psoriasis, a recent serious infection or a history of chronic or recurrent infectious disease, or a known malignant condition. Before enrollment, patients could not have received conventional systemic therapy or phototherapy within 4 weeks before enrollment; topical psoriasis agents within 2 weeks; investigational drugs within 4 weeks or 5 half-lives, whichever was longer; or biologic agents within 3 months or 5 half-lives, whichever was longer.

Patients were randomized to receive either subcutaneous ustekinumab $45 \mathrm{mg}(\mathrm{n}=209)$ or $90 \mathrm{mg}(\mathrm{n}=347)$ at weeks 0 and 4 or subcutaneous etanercept $50 \mathrm{mg}(\mathrm{n}=347)$ twice weekly through week 12 . The primary endpoint was the proportion of patients who achieved a PASI 75 at week 12. The secondary endpoints were the proportion of patients achieving a PGA score of cleared or minimal at week 12 and the proportion of patients achieving a PASI 90 score at week 12. Patients in the etanercept group who did not demonstrate a PASI 75 score at week 12 received ustekinumab $90 \mathrm{mg}$ at weeks 16 and 20 . Patients not achieving a PASI 75 score in the ustekinumab group at week 12 got an additional dose of ustekinumab.

The study enrolled 903 patients. Baseline demographic and disease characteristics were similar among treatment groups. Patients were an average age of 45 years and had an average duration of psoriasis of 18.8 years, with a mean involved BSA of $25 \%$. A total of $61.7 \%, 52.4 \%$, and $57.3 \%$ in the ustekinumab $45 \mathrm{mg}$ and $90 \mathrm{mg}$ and etanercept groups, respectively, had tried PUVA, methotrexate, acitretin, or cyclosporine prior to study initiation. A total of $12.8 \%, 10.4 \%$, and $11.8 \%$ in the ustekinumab $45 \mathrm{mg}$ and $90 \mathrm{mg}$ and etanercept groups, respectively, had tried an autoimmune biologic-alefacept, efalizumab, infliximab, or adalimumab-prior to study initiation.

At week 12, a total of $67.5 \%$ of patients treated with ustekinumab $45 \mathrm{mg}$ and $73.8 \%$ treated with $90 \mathrm{mg}$ achieved a PASI 75 score compared with $56.8 \%$ of patients treated with etanercept ( $P=0.012$ for ustekinumab $45 \mathrm{mg}$ vs. etanercept and $P<0.001$ for ustekinumab $90 \mathrm{mg}$ vs. etanercept). A PGA score of cleared or minimal was achieved by $65.1 \%$ of patients treated with ustekinumab $45 \mathrm{mg}$ and $70.6 \%$ for $90 \mathrm{mg}$ compared with $49.0 \%$ of patients treated with etanercept at week $12(P<0.001$ for both ustekinumab groups vs. placebo). A PASI 90 score at week 12 was achieved by $36.4 \%$ of patients treated with ustekinumab $45 \mathrm{mg}$ and $44.7 \%$ for $90 \mathrm{mg}$, compared with $23.1 \%$ of patients treated with etanercept $(P<0.001$ for both ustekinumab groups vs. placebo). A total of $48.9 \%$ of patients not achieving a response in the etanercept group achieved a PASI 75 score when treated with ustekinumab $90 \mathrm{mg}$, and $23.4 \%$ had $90 \%$ improvement.

RADIATE: Tocilizumab in RA patients with prior TNF failure. The efficacy of tocilizumab in the treatment of patients with moderate to severe RA with prior TNF failure was assessed in a 24-week, double-blind, randomized, placebo-controlled trial (Table 3). ${ }^{28}$ Patients eligible for enrollment were aged 18 years or older and had moderate to severe RA and failed to respond or were intolerant to previous treatment with 1 or more TNF antagonists in the previous year. Patients had active RA for 6 months or more and discontinued all prior therapies (except methotrexate) prior to study initiation. Infliximab or adalimumab had to be discontinued 8 weeks prior and etanercept 2 
weeks prior to the start of the study. Exclusion criteria included prior treatment with cell-depleting agents (e.g., azathioprine), uncontrolled medical conditions, history of malignancy, other inflammatory diseases or recurrent infection, abnormal liver function, leukopenia, neutropenia, or thrombocytopenia.

Patients were randomized to tocilizumab $8 \mathrm{mg}$ per kilogram (kg), tocilizumab $4 \mathrm{mg}$ per $\mathrm{kg}$, or placebo infusion every 4 weeks. Infusions were administered over 1 hour. All patients were treated with a stable dose of methotrexate (10-25 mg weekly) and folate. Stable oral corticosteroids (prednisone 10 mg or less or equivalent) and nonsteroidal anti-inflammatory drugs (NSAIDs) were permitted, but other disease-modifying antirheumatic drugs (DMARDs) were not allowed. The primary endpoint was the proportion of patients achieving an American College of Rheumatology criteria 20\% improvement in signs or symptoms of RA (ACR 20) at week 24. Secondary endpoints included the proportion of patients achieving an ACR 50 or ACR 70, and patients achieving disease remission defined as a disease activity score of 28 joints (DAS 28) less than 2.6.

The study enrolled 499 patients. Baseline characteristics were similar between groups. Average disease duration prior to the study was $12.6,11.0$, and 11.4 years in the tocilizumab $8 \mathrm{mg}$ per $\mathrm{kg}, 4 \mathrm{mg}$ per $\mathrm{kg}$, and placebo groups, respectively. A total of $50 \%, 47 \%$, and $42 \%$ of patients in the tocilizumab $8 \mathrm{mg}$ per $\mathrm{kg}, 4 \mathrm{mg}$ per $\mathrm{kg}$, and placebo groups, respectively, had tried 1 prior TNF agent. Two prior TNFs had been tried in $32 \%, 41 \%$, and $42 \%$, respectively, and 3 or more TNFs had been tried in 18\%,12\%, and 14\%, respectively. Approximately $95 \%$ of patients discontinued prior TNF therapy due to inadequate efficacy. An ACR 20 at week 24 was achieved by significantly more study participants in the tocilizumab $8 \mathrm{mg}$ per $\mathrm{kg}(50.0 \%)$ and $4 \mathrm{mg}$ per $\mathrm{kg}(30.4 \%)$ groups than the placebo group (10.1\%, $P<0.001$ for both tocilizumab groups compared with placebo). An ACR 50 was achieved by $28.8 \%$ and $16.8 \%$ of patients in the tocilizumab $8 \mathrm{mg}$ per $\mathrm{kg}$ and $4 \mathrm{mg}$ per $\mathrm{kg}$ groups, respectively, compared with $3.8 \%$ in the placebo group $(P<0.001$ for both tocilizumab groups compared with placebo). An ACR 70 was achieved by $12.4 \%$ and $5.0 \%$ of patients in the tocilizumab $8 \mathrm{mg}$ per $\mathrm{kg}$ and $4 \mathrm{mg}$ per kg groups, respectively, compared with $1.3 \%$ for the placebo group. The ACR 70 response was significant compared with placebo for the tocilizumab $8 \mathrm{mg}$ per $\mathrm{kg}$ group $(P=0.001)$ but not the $4 \mathrm{mg}$ per $\mathrm{kg}$ group $(P=0.1)$. Disease remission was reported at week 24 in $30.1 \%, 7.6 \%$, and $1.6 \%$ of patients in the tocilizumab $8 \mathrm{mg}$ per $\mathrm{kg}, 4 \mathrm{mg}$ per $\mathrm{kg}$, and placebo groups, respectively $(P=0.001$ for $8 \mathrm{mg}$ per $\mathrm{kg}$ compared with placebo and $P=0.053$ for $4 \mathrm{mg}$ per $\mathrm{kg}$ compared with placebo).

OPTION: Tocilizumab in RA patients with prior methotrexate failure. The OPTION trial was a 24 -week, phase 3 doubleblind, randomized, placebo-controlled trial (Table 3). ${ }^{29}$ Patients eligible for enrollment were adults with moderate to severe RA
TABLE 3 Primary Endpoint Results from Phase 3 Trials of Tocilizumab

\begin{tabular}{|c|c|c|}
\hline \multicolumn{3}{|c|}{ RADIATE $^{28}$} \\
\hline Drug & $\begin{array}{c}\text { ACR } 20 \text { Response } \\
\text { at Week } 24(\%)\end{array}$ & $\begin{array}{c}P \text { Value Compared } \\
\text { with Placebo }\end{array}$ \\
\hline $\begin{array}{l}\text { Tocilizumab } 4 \text { mg per } \\
\mathrm{kg}+\operatorname{MTX}(\mathrm{n}=163)\end{array}$ & 30.4 & $<0.001$ \\
\hline $\begin{array}{l}\text { Tocilizumab } 8 \text { mg per } \\
\mathrm{kg}+\operatorname{MTX}(\mathrm{n}=175)\end{array}$ & 50.0 & $<0.001$ \\
\hline Placebo + MTX $(n=160)$ & 10.1 & - \\
\hline \multicolumn{3}{|c|}{ OPTION $^{29}$} \\
\hline Drug & $\begin{array}{l}\text { ACR } 20 \text { Response } \\
\text { at Week } 24(\%)\end{array}$ & $\begin{array}{c}P \text { Value Compared } \\
\text { with Placebo }\end{array}$ \\
\hline $\begin{array}{l}\text { Tocilizumab } 4 \text { mg per } \\
\operatorname{kg}+\operatorname{MTX}(n=214)\end{array}$ & 48.0 & $<0.001$ \\
\hline $\begin{array}{l}\text { Tocilizumab } 8 \text { mg per } \\
\mathrm{kg}+\operatorname{MTX}(\mathrm{n}=205)\end{array}$ & 59.0 & $<0.001$ \\
\hline Placebo + MTX $(n=204)$ & 26.0 & - \\
\hline \multicolumn{3}{|c|}{ TOWARD $^{31}$} \\
\hline Drug & $\begin{array}{c}\text { ACR } 20 \text { Response at } \\
\text { Week } 24(\%)\end{array}$ & $\begin{array}{c}P \text { Value Compared } \\
\text { with Placebo }\end{array}$ \\
\hline $\begin{array}{l}\text { Tocilizumab } 8 \text { mg per } \\
\text { kg+DMARD }(n=802)\end{array}$ & 60.8 & $<0.001$ \\
\hline Placebo + DMARD $(n=414)$ & 24.5 & - \\
\hline \multicolumn{3}{|c|}{ SAMURAI $^{32}$} \\
\hline Drug & $\begin{array}{c}\text { Mean TSS Change at } \\
\text { Weeks } 28 \text { and } 52\end{array}$ & $\begin{array}{c}P \text { Value Compared } \\
\text { with Placebo }\end{array}$ \\
\hline \multirow[t]{2}{*}{$\begin{array}{l}\text { Tocilizumab } 8 \mathrm{mg} \text { per } \mathrm{kg} \\
(\mathrm{n}=157)\end{array}$} & $\begin{array}{c}1.9(95 \% \mathrm{CI}=1.2-2.6) \\
\text { at week } 28\end{array}$ & $<0.05$ \\
\hline & $\begin{array}{c}2.3(95 \% \mathrm{CI}=1.5-3.2) \\
\text { at week } 52\end{array}$ & $<0.01$ \\
\hline \multirow[t]{2}{*}{$\begin{array}{l}\text { Placebo } \\
(\mathrm{n}=145)\end{array}$} & $\begin{array}{c}4.5(95 \% \mathrm{CI}=3.1-6.0) \\
\text { at week } 28\end{array}$ & - \\
\hline & $\begin{array}{c}6.1(95 \% \mathrm{CI}=4.2-8.0) \\
\text { at week } 52\end{array}$ & - \\
\hline \multicolumn{3}{|c|}{ AMBITION $^{33}$} \\
\hline Drug & $\begin{array}{l}\text { ACR } 20 \text { Response } \\
\text { at Week } 24(\%)\end{array}$ & $\begin{array}{c}P \text { Value Compared } \\
\text { with MTX }\end{array}$ \\
\hline $\begin{array}{l}\text { Tocilizumab } 8 \mathrm{mg} \text { per } \mathrm{kg} \\
(\mathrm{n}=265)\end{array}$ & 69.9 & $<0.001$ \\
\hline $\operatorname{MTX}(n=259)$ & 52.5 & - \\
\hline
\end{tabular}

ACR $20=$ American College of Rheumatology criteria for $20 \%$ improvement in signs or symptoms of rheumatoid arthritis.

$C I=$ confidence interval; DMARD = disease-modifying antirheumatic drug; $\mathrm{kg}=$ kilogram; $m g=$ milligram; MTX=methotrexate; TSS=total Sharp score.

of at least 6 months duration and an inadequate response to methotrexate. Patients had to be treated with methotrexate for at least 12 weeks prior to the study with a stable dose of $10 \mathrm{mg}$ to $25 \mathrm{mg}$ weekly for at least 8 weeks. Patients were excluded if they had other autoimmune disorders, currently active or recurrent infections, or had an inflammatory joint disease other than RA.

Patients were randomized to either tocilizumab $8 \mathrm{mg}$ per 
$\mathrm{kg}, 4 \mathrm{mg}$ per $\mathrm{kg}$, or placebo infusion once every 4 weeks as a 1-hour infusion for 24 weeks. All patients continued their baseline stable methotrexate regimen (10-25 mg weekly). Oral corticosteroids (prednisone $10 \mathrm{mg}$ or less or equivalent) and NSAIDs were permitted if the patient had received a stable dose for at least 6 weeks prior to the study. DMARDs (other than methotrexate) or biologics were discontinued prior to the beginning of the study. The primary endpoint was achievement of an ACR 20 score at week 24. Secondary endpoints included achievement of an ACR 50 score or ACR 70 score and achievement of disease remission (DAS $28<2.6$ ).

The study enrolled 622 patients with a mean age of 51 years $(71 \%$ female). Mean disease duration was 7.5 years. Concomitant use of corticosteroids or NSAIDs was similar between groups. Mean methotrexate dose was 14.5, 14.7, and $14.8 \mathrm{mg}$ weekly in the tocilizumab $8 \mathrm{mg}$ per $\mathrm{kg}, 4 \mathrm{mg}$ per $\mathrm{kg}$, and placebo groups, respectively. An ACR 20 score at week 24 was achieved by $59 \%, 48 \%$, and $26 \%$ in the tocilizumab $8 \mathrm{mg}$ per kg, $4 \mathrm{mg}$ per kg, and placebo groups, respectively $(P<0.001$ for both tocilizumab groups compared with placebo). An ACR 50 score at week 24 was achieved by $44 \%, 31 \%$, and $11 \%$ in the tocilizumab $8 \mathrm{mg}$ per $\mathrm{kg}, 4 \mathrm{mg}$ per $\mathrm{kg}$, and placebo groups, respectively $(P<0.001$ for both tocilizumab groups compared with placebo). An ACR 70 score at week 24 was achieved by $22 \%, 12 \%$, and $2 \%$ of patients in the tocilizumab $8 \mathrm{mg}$ per $\mathrm{kg}$, $4 \mathrm{mg}$ per $\mathrm{kg}$, and placebo groups, respectively $(P<0.001$ for both groups compared with placebo). Disease remission was reached by $27 \%, 13 \%$, and $0.8 \%$ of patients in the tocilizumab $8 \mathrm{mg}$ per $\mathrm{kg}, 4 \mathrm{mg}$ per $\mathrm{kg}$, and placebo groups, respectively $(P<0.05$ for both groups compared with placebo).

Treatment in RA patients, comparison of methotrexate only, methotrexate plus tocilizumab, and tocilizumab only. A European trial reported by Maini et al. (2006) enrolled 350 RA patients for a 20-week, double-blind, placebo-controlled, randomized trial. ${ }^{30}$ Patients with active RA despite previous treatment with methotrexate and on a stable dose for at least 4 weeks prior to randomization were enrolled. Patients were randomized to 1 of 7 groups: tocilizumab $2 \mathrm{mg}$ per $\mathrm{kg}, 4 \mathrm{mg}$ per $\mathrm{kg}$, or $8 \mathrm{mg}$ per $\mathrm{kg}$ plus placebo capsule; tocilizumab $2 \mathrm{mg}$ per $\mathrm{kg}$, $4 \mathrm{mg}$ per $\mathrm{kg}$, or $8 \mathrm{mg}$ per $\mathrm{kg}$ plus methotrexate; or placebo infusion plus methotrexate. The primary endpoint was an ACR 20 score at week 16. Secondary endpoints included ACR 50 and ACR 70 scores at week 16.

An ACR 20 score at week 16 was achieved by $31 \%, 61 \%$, and $63 \%$ of patients in the tocilizumab $2 \mathrm{mg}$ per $\mathrm{kg}, 4 \mathrm{mg}$ per $\mathrm{kg}$, and $8 \mathrm{mg}$ per $\mathrm{kg}$ monotherapy groups, respectively, compared with $41 \%$ for methotrexate monotherapy $(P<0.05$ for $4 \mathrm{mg}$ per $\mathrm{kg}$ and $8 \mathrm{mg}$ per $\mathrm{kg}$ compared with methotrexate, $P>0.05$ [exact $P$ value not reported] for $2 \mathrm{mg}$ per $\mathrm{kg}$ compared with methotrexate). An ACR 20 score at week 16 was achieved by $64 \%, 63 \%$, and $74 \%$ of patients in the tocilizumab $2 \mathrm{mg}$ per $\mathrm{kg}$,
$4 \mathrm{mg}$ per $\mathrm{kg}$, and $8 \mathrm{mg}$ per $\mathrm{kg}+$ methotrexate group compared with $41 \%$ in the methotrexate monotherapy group $(P<0.05$ for all comparisons to methotrexate monotherapy). An ACR 50 score was achieved by $53 \%$ of patients in the tocilizumab $8 \mathrm{mg}$ per $\mathrm{kg}+$ methotrexate group compared with $29 \%$ in the methotrexate monotherapy group $(P<0.05)$. An ACR 70 was achieved by $37 \%$ of patients in the tocilizumab $8 \mathrm{mg}$ per $\mathrm{kg}+$ methotrexate group compared with $16 \%$ in the methotrexate monotherapy group $(P<0.05)$. Rates of achievement of ACR 50 and ACR 70 scores did not differ for any of the other tocilizumab groups compared with methotrexate monotherapy.

TOWARD: Treatment in RA patients in combination with DMARDs (except TNFs). The TOWARD trial was a 24 -week, phase 3, double-blind, randomized, placebo-controlled trial (Table 3). ${ }^{31}$ Patients eligible for enrollment were aged 18 years or older and had moderate to severe RA for at least 6 months and were currently being treated with a conventional DMARD at a stable dose for 8 weeks or more prior to study entry. Permitted conventional DMARDs included methotrexate, chloroquine, hydroxychloroquine, parenteral gold, sulfasalazine, azathioprine, and leflunomide. Exclusion criteria included previous treatment and failure with a TNF antagonist or prior treatment with a cell-depleting agent.

Patients were randomized 2:1 to either tocilizumab $8 \mathrm{mg}$ per $\mathrm{kg}$ or placebo once every 4 weeks. Tocilizumab and placebo infusions were administered over 1 hour. All patients continued their conventional DMARD therapy at a stable dose. Oral corticosteroids ( $<10 \mathrm{mg}$ prednisone or equivalent) and NSAIDs were permitted if the patient had received a stable dose for at least 6 weeks prior to the study. The primary endpoint was achievement of an ACR 20 score at week 24. Secondary endpoints included achievement of an ACR 50 score or ACR 70 score and achievement of disease remission (DAS $28<2.6$ ).

The study enrolled 1,220 patients with a mean age of 53.5 years $(82.5 \%$ female). Mean disease duration was 9.8 years. One DMARD was used in $77 \%$ and $75 \%$ in the tocilizumab $8 \mathrm{mg}$ per $\mathrm{kg}$ and placebo groups, respectively. Two or more DMARDs were used by $22 \%$ and $24 \%$ of patients in the tocilizumab $8 \mathrm{mg}$ per $\mathrm{kg}$ and placebo groups, respectively. The most commonly used DMARD was methotrexate (mean dose $15 \mathrm{mg}$ weekly) in $75.8 \%$ and $73.9 \%$ of patients in the tocilizumab 8 mg per kg and placebo groups, respectively. An ACR 20 score at week 24 was achieved by $60.8 \%$ and $24.5 \%$ in the tocilizumab $8 \mathrm{mg}$ per $\mathrm{kg}$ and placebo groups, respectively $(P<0.001)$. An ACR 50 score at week 24 was achieved by $37.6 \%$ and $9.0 \%$ in the tocilizumab $8 \mathrm{mg}$ per $\mathrm{kg}$ and placebo groups, respectively $(P<0.001)$. An ACR 70 score at week 24 was achieved by $20.5 \%$ and $2.9 \%$ of patients in the tocilizumab $8 \mathrm{mg}$ per $\mathrm{kg}$ and placebo groups, respectively $(P<0.001)$. Disease remission was reached by $30.2 \%$ and $3.4 \%$ of patients in the tocilizumab $8 \mathrm{mg}$ per $\mathrm{kg}$ and placebo groups, respectively $(P<0.001)$. 
SAMURAI: Tocilizumab compared with DMARD in joint damage progression. The efficacy of tocilizumab in the inhibition of progression of structural joint damage in RA was assessed in a 52-week, open label, x-ray reader blinded, controlled trial. ${ }^{32}$ Adult patients aged 20 years or older with active RA and a disease duration between 6 months and 5 years were enrolled. All patients had an inadequate efficacy response to at least 1 DMARD or immunosuppressant. Exclusion criteria included medical history of a serious allergic reaction, significant underlying disease process other than RA, or active infection.

Patients were randomized to receive either tocilizumab 8 mg per kg monotherapy once every 4 weeks or conventional DMARD. DMARDs or immunosuppressants were discontinued in the tocilizumab group at the beginning of the study. Patients in the DMARD group were treated with a DMARD (except TNFs) or immunosuppressant at the discretion of the treating physician. Oral corticosteroids (prednisone $10 \mathrm{mg}$ or less or equivalent) were permitted if the patient had received a stable dose for at least 2 weeks prior to the study. Oral NSAIDs were allowed during the trial. The primary endpoint was the change in the mean modified total Sharp score (TSS) at weeks 28 and 52 .

The study enrolled 306 patients (mean age 53 years) with a mean duration of disease of 2.3 years. Demographic and baseline characteristics did not differ between groups. A total of $37 \%, 30 \%$, and $22 \%$ of patients in the DMARD group received methotrexate in combination with DMARDs, methotrexate monotherapy, and DMARDs other than methotrexate, respectively. At baseline, the mean (standard deviation) TSS was 30.6 (42.0) and 28.3 (43.9) in the tocilizumab and DMARD groups, respectively. Mean change in the TSS at week 28 was 1.9 (95\% $\mathrm{CI}=1.2-2.6)$ and $4.5(95 \% \mathrm{CI}=3.1-6.0)$ in the tocilizumab and DMARD groups, respectively $(P<0.05)$. Mean change in the TSS at week 52 was $2.3(95 \% \mathrm{CI}=1.5-3.2)$ and $6.1(95 \%$ $\mathrm{CI}=4.2-8.0)$ in the tocilizumab and DMARD groups, respectively $(P<0.01)$. These data demonstrate that tocilizumab significantly inhibited the progression of structural joint damage compared with conventional DMARD therapy.

AMBITION: Tocilizumab monotherapy compared with methotrexate monotherapy. The AMBITION trial was a 24-week, phase 3, double-blind, randomized, placebo-controlled trial. ${ }^{33}$ Patients eligible for enrollment were aged 18 years or older and had moderate to severe RA for at least 3 months. Exclusion criteria included treatment with methotrexate in the 6 months prior to trial initiation or any discontinuation of prior methotrexate and/or TNF antagonist due to intolerance or lack of efficacy.

Patients were randomized 1:1:1 to either tocilizumab $8 \mathrm{mg}$ per kg every 4 weeks, methotrexate $7.5 \mathrm{mg}$ initially with titration to $20 \mathrm{mg}$ weekly by week 8 , or placebo for 8 weeks and then tocilizumab $8 \mathrm{mg}$ per $\mathrm{kg}$ every 4 weeks. Tocilizumab and placebo infusions were administered over 1 hour. Oral corticosteroids (prednisone $10 \mathrm{mg}$ or less or equivalent) and NSAIDs were permitted if the patient had received a stable dose for at least 6 weeks prior to the study. The primary endpoint was achievement of an ACR 20 score at week 24. Secondary endpoints included achievement of an ACR 50 score or ACR 70 score and achievement of disease remission (DAS $28<2.6$ ). The primary efficacy analysis was a noninferiority comparison of tocilizumab and methotrexate using the per protocol population. If noninferiority of tocilizumab was met, then superiority was assessed in the intention-to-treat (ITT) group.

The study enrolled 673 patients with a mean age of approximately 50 years ( $81 \%$ female). Mean disease duration was approximately 6.3 years. The majority of patients (approximately 66\% in each group) were methotrexate naive The mean number of previous DMARDs/TNFs was 0.5 , and $40 \%$ of patients had received prior oral steroids. An ACR 20 at week 24 was achieved by $69.9 \%$ and $52.5 \%$ in the tocilizumab $8 \mathrm{mg}$ per $\mathrm{kg}$ and methotrexate groups, respectively (weighted difference $0.21,95 \% \mathrm{CI}=0.13-0.29)$, meeting the endpoint for noninferiority. An analysis in the ITT population demonstrated the superiority of tocilizumab $8 \mathrm{mg}$ per $\mathrm{kg}$ to methotrexate (weighted difference 0.19, 95\% CI=0.34-0.52, P<0.001). An ACR 50 at week 24 was achieved by $44.1 \%$ and $33.5 \%$ in the tocilizumab $8 \mathrm{mg}$ per $\mathrm{kg}$ and methotrexate groups, respectively (weighted difference 0.12, 95\% CI=0.04-0.20, P=0.002). An ACR 70 score at week 24 was achieved by $28.0 \%$ and $15.1 \%$ of patients in the tocilizumab $8 \mathrm{mg}$ per $\mathrm{kg}$ and methotrexate groups, respectively (weighted difference $0.14,95 \% \mathrm{CI}=0.07$ $0.22, P<0.001)$.

\section{Safety}

Ustekinumab. Infection was the most common adverse event in patients treated with ustekinumab in clinical trials (Table 4). Infections were reported in $73.3 \%$ and $71.9 \%$ of patients in the ustekinumab $45 \mathrm{mg}$ and $90 \mathrm{mg}$ groups, respectively, through 100 weeks in the PHOENIX-2 trial. ${ }^{34}$ During the double-blind phase of PHOENIX-2 (12 weeks) infections occurred in 21.5\%, $22.4 \%$, and $20.0 \%$ of patients in the ustekinumab $45 \mathrm{mg}, 90 \mathrm{mg}$, and placebo groups, respectively. ${ }^{34}$ Nasopharyngitis and upper respiratory tract infection were the most commonly reported events. ${ }^{34}$ During the double-blind portion of the phase 3 trials, the incidence of infection was similar between ustekinumab and placebo. The incidence of serious infections during the double-blind portion of the phase 3 trials was $0.3 \%$ and $0.4 \%$ in the ustekinumab and placebo groups, respectively. ${ }^{34}$

Patients treated with ustekinumab may be at an increased risk for malignancy. Animal models have shown that blockade of the IL-12/23 subunit increases the risk of malignancy. ${ }^{34,35} \mathrm{~A}$ total of 30 malignancies were reported in 26 patients treated with ustekinumab over 100 weeks of the PHOENIX-2 trial. ${ }^{34}$ 
Formulary Review of 2 New Biologic Agents: Tocilizumab for Rheumatoid Arthritis and Ustekinumab for Plaque Psoriasis

TABLE 4 Safety Warnings for Approved Autoimmune Biologics

\begin{tabular}{|c|c|c|}
\hline Drug & Black-Box Warnings & Other Label Warnings \\
\hline Adalimumab (Humira) ${ }^{47}$ & Serious infections, malignancy & $\begin{array}{l}\text { Hepatitis B reactivation, hematologic events, hypersensitivity, } \\
\text { demyelinating syndromes, heart failure }\end{array}$ \\
\hline Etanercept (Enbrel) ${ }^{46}$ & Serious infections, malignancy & Hepatitis B reactivation, hematologic events, demyelinating syndromes \\
\hline Infliximab (Remicade) ${ }^{38}$ & Serious infections, malignancy, T cell lymphoma & $\begin{array}{l}\text { Hepatitis B reactivation, hepatotoxicity, hematologic events, } \\
\text { hypersensitivity, demyelinating syndromes, heart failure }\end{array}$ \\
\hline Certolizumab (Cimzia) ${ }^{48}$ & Serious infections, malignancy & $\begin{array}{l}\text { Hepatitis B reactivation, hematologic events, hypersensitivity, } \\
\text { demyelinating syndromes, heart failure }\end{array}$ \\
\hline Alefacept (Amevive) ${ }^{49}$ & None & Lymphopenia, serious infections \\
\hline Anakinra (Kineret) ${ }^{50}$ & None & Serious infections, use with TNF antagonists \\
\hline Abatacept (Orencia) $)^{53}$ & None & $\begin{array}{l}\text { Use with TNF antagonists, hypersensitivity, serious infections, increased } \\
\text { safety risk in COPD patients }\end{array}$ \\
\hline Rituximab (Rituxan) 51 & $\begin{array}{l}\text { Fatal infusion reactions, tumor lysis syndrome, } \\
\text { severe mucocutaneous reactions, progressive } \\
\text { multifocal leukoencephalopathy }\end{array}$ & $\begin{array}{l}\text { Hepatitis B reactivation, infections, cardiac arrhythmias, infusion } \\
\text { reactions, renal dysfunction, bowel perforation }\end{array}$ \\
\hline Golimumab (Simponi) $)^{52}$ & Serious infections, malignancy & $\begin{array}{l}\text { Hepatitis B reactivation, congestive heart failure, demyelinating } \\
\text { syndromes, hematologic events }\end{array}$ \\
\hline Ustekinumab (Stelara) $^{16}$ & None & Infections, malignancies, RPLS \\
\hline Tocilizumab (Actemra) ${ }^{17}$ & Serious infections & $\begin{array}{l}\text { Gastrointestinal perforations, neutropenia, thrombocytopenia, LFT and } \\
\text { lipids increases, hypersensitivity, demyelinating syndromes }\end{array}$ \\
\hline
\end{tabular}

Twelve patients were diagnosed with solid tumors that included prostate, bladder, pancreatic, breast, colon, and endometrial cancers. ${ }^{34}$ An evaluation of ustekinumab and cancer risk is severely limited by the lack of long-term data in large populations. Safety data beyond 2 years are not currently available.

The ACCEPT trial provides data on the comparative safety between ustekinumab and etanercept; however, this trial lasted only 12 weeks. ${ }^{20}$ Adverse events of any kind were experienced by $70.0 \%, 66.0 \%$, and $69.2 \%$ of patients in the etanercept, ustekinumab $45 \mathrm{mg}$, and ustekinumab $90 \mathrm{mg}$ groups, respectively, by week 12 ( $P$ values for comparisons were not reported). ${ }^{20}$ Discontinuation due to adverse events occurred in $2.3 \%, 1.9 \%$, and $1.2 \%$ of patients in the etanercept, ustekinumab $45 \mathrm{mg}$, and ustekinumab $90 \mathrm{mg}$ groups, respectively. ${ }^{20}$ Injection site reactions, predominantly mild, occurred in $24.8 \%$ of patients treated with etanercept compared with $4.3 \%$ and $3.7 \%$ of patients in the ustekinumab $45 \mathrm{mg}$ and 90 mg groups, respectively. ${ }^{20}$ Infection rates were similar between groups, occurring in $29.1 \%, 30.6 \%$, and $29.7 \%$ of patients in the etanercept, ustekinumab $45 \mathrm{mg}$, and ustekinumab $90 \mathrm{mg}$ groups, respectively. ${ }^{20}$ No comparative data beyond 12 weeks have been reported.

Tocilizumab. Tocilizumab has been shown to increase the risk of neutropenia. In the 24-week RADIATE trial, transient neutropenia (neutrophils $<2,000$ cells per cubic millimeter $\left[\mathrm{mm}^{3}\right]$ ) occurred in $28.0 \%, 20.3 \%$, and $<1.0 \%$ of patients in the tocilizumab $8 \mathrm{mg}$ per $\mathrm{kg}, 4 \mathrm{mg}$ per $\mathrm{kg}$, and placebo groups, respectively (Table 4). ${ }^{28}$ Four patients in the tocilizumab 8 mg per $\mathrm{kg}(\mathrm{n}=175)$ and 1 in the $4 \mathrm{mg}$ per $\mathrm{kg}(\mathrm{n}=163)$ groups experienced an absolute neutrophil count less than 500 per $\mathrm{mm}^{3}$ and were withdrawn from the study. ${ }^{28}$ The 24-week OPTION trial found higher rates of grade 1 ( $>1,500$ cells per $\mathrm{mm}^{3} ; 18.8 \%$ vs. $4.3 \%$ placebo), grade 2 (1,000-1,500 cells per $\mathrm{mm}^{3} ; 11.6 \%$ vs. $0.5 \%$ placebo), and grade 3 (500-1,000 cells per $\mathrm{mm}^{3} ; 3.7 \%$ vs. $0 \%$ placebo) neutropenia in the tocilizumab groups compared with placebo. ${ }^{29}$ The long-term extension trial involving 5 years of follow-up $(n=143)$ documented grade 2 neutropenia in 17 (11.9\%) patients and grade 3 in 9 (6.3\%) patients. ${ }^{36}$ No patients discontinued tocilizumab in the longterm extension due to neutropenia. ${ }^{36}$ Monitoring of neutrophil counts is recommended every 4-8 weeks, and patients experiencing a neutrophil count less than 500 cells per $\mathrm{mm}^{3}$ should discontinue tocilizumab. ${ }^{17} \mathrm{~A}$ connection between infections and tocilizumab-associated neutropenia has not been proven in clinical trials; however, the risk of infection in neutropenic patients has been well documented in other disease states (e.g., cancer). ${ }^{17}$

Infection was the most common adverse event associated with tocilizumab in clinical trials. According to an FDA analysis, combination therapy of tocilizumab $8 \mathrm{mg}$ per $\mathrm{kg}$ or $4 \mathrm{mg}$ per $\mathrm{kg}$ and a DMARD had infection rates of 133 events and 127 events per 100 patient years, respectively, compared with 112 events per 100 patient years in the placebo plus DMARD groups. ${ }^{17}$ Serious infections occurred more commonly in the tocilizumab monotherapy cohort (3.6 events per 100 patient years) compared with methotrexate monotherapy (1.5 events per 100 patient years, $P$ values not reported). ${ }^{17}$ A 5-year extension trial involving 143 patients treated with tocilizumab monotherapy (median duration of treatment 66.7 months) 


\section{FIGURE 3 PMPM Spending for Skin and Arthritis Medications Including Autoimmune Biologics ${ }^{\mathrm{a}}$}

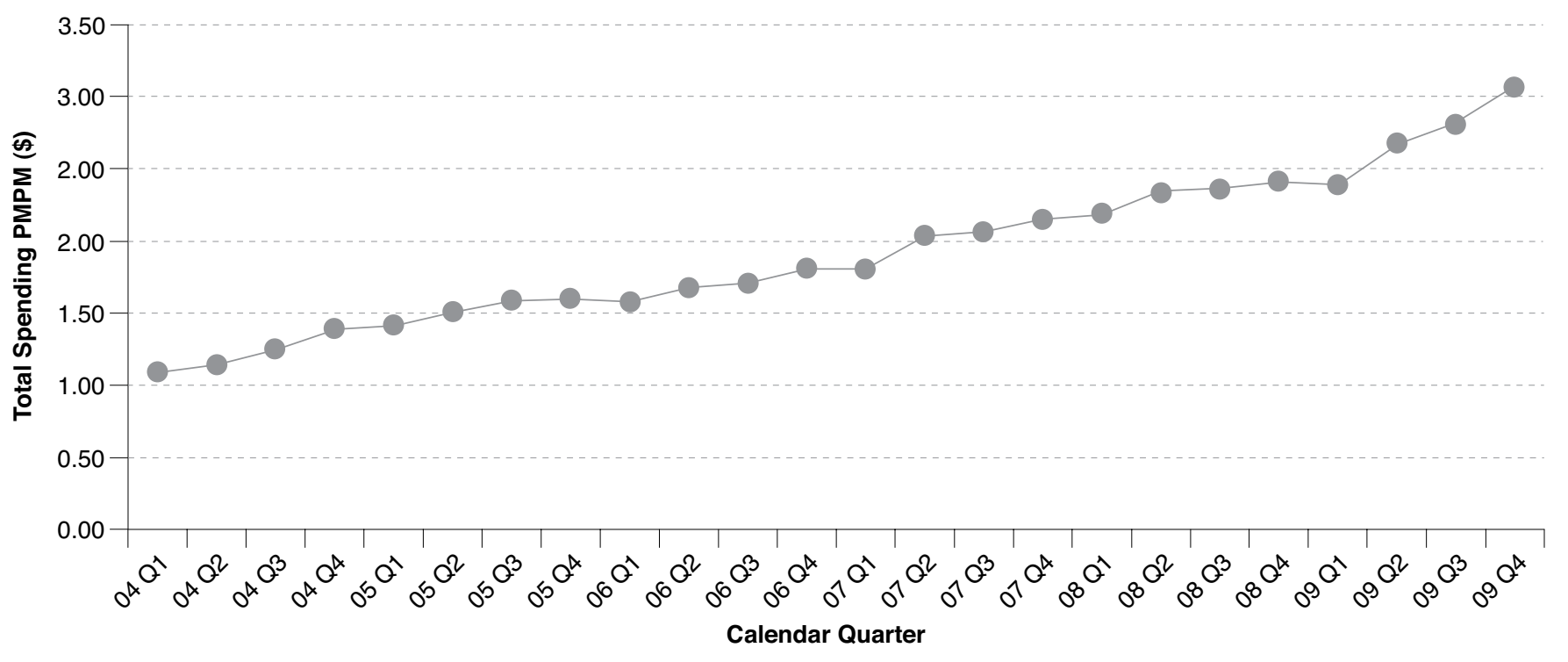

aSpending is defined as allowed charge, the sum of plan and member cost, and includes ingredient cost and pharmacy dispensing fees, PMPM for pharmacy claims for approximately 8.7 million commercial plan members through 2009 Q4.43

PMPM = per member per month

found serious infections were reported in $17.5 \%$ of patients for a rate of 5.7 events per 100 patient years. ${ }^{36}$ This rate is higher than the 3.6 events calculated by the FDA using 6-month clinical trial data. Combination tocilizumab $8 \mathrm{mg}$ per $\mathrm{kg}$ or 4 mg per kg plus DMARD had serious infection rates of 5.3 and 4.4 events per 100 patient years, respectively, compared with 3.9 events per 100 years in the placebo plus DMARD group. ${ }^{17}$ The most common serious infections were pneumonia, urinary tract infection, and cellulitis. ${ }^{17}$ Fatal infections were rare $(0.13$ events per 100 patient years across all groups). ${ }^{17}$ Patients should be closely monitored for signs and symptoms of infection prior to and during treatment with tocilizumab.

Malignancy is a common concern with biologics for autoimmune disease. An FDA analysis of the 6-month trials of tocilizumab reported 15 malignancies in the tocilizumab group and 8 in the control group. ${ }^{17}$ Exposure-adjusted incidence of malignancy was similar in the tocilizumab groups (1.32 events per 100 patient years) and in the placebo plus DMARD group (1.37 events per 100 patient years) ${ }^{17}$ However, the risk of malignancy is complicated by the limited long-term data for tocilizumab. A 52-week study reported 3 malignancies in the tocilizumab group (2 breast cancer and 1 colon cancer) compared with no malignancies in the DMARD group. ${ }^{32}$ The 5 -year extension trial found 4 malignancies (breast, bladder, colon, and intraductal cancers) in patients treated with tocilizumab for a rate of 0.7 events per 100 patient years. ${ }^{36}$

\section{- Managed Care Considerations}

Ustekinumab and tocilizumab are new options in the treatment of autoinflammatory disease with unique mechanisms of action. The clinical trial data for ustekinumab include the first results from a phase 3 comparison to an active autoimmune agent, showing superiority to etanercept for the treatment of psoriasis. ${ }^{20}$ Tocilizumab has demonstrated efficacy in patients with an inadequate response to 1 or more TNF antagonists. ${ }^{28}$ Comparative efficacy trials and studies in patients with multiple prior failures provide useful data to clinicians and managed care decision makers. However, questions remain regarding (a) how both agents will be used in clinical practice, (b) shortand long-term safety, and (c) the additional value brought to patients and payers.

Long-term safety data are sparse for both ustekinumab and tocilizumab. There are 5-year data available for tocilizumab but only for 143 patients. ${ }^{36}$ Safety data beyond 2 years of use of ustekinumab are unknown. Biologics, like many drugs, require years of extensive use before the full adverse event profile is understood. Infliximab was approved in 1998 with few warnings and precautions including hypersensitivity, autoimmunity, infection, and possible malignancy. ${ }^{37}$ No boxed warnings were present at approval. ${ }^{37}$ The prescribing information approved in 2009 for infliximab now includes warnings for hepatotoxicity, avoidance in patients with heart failure, reactivation of hepatitis $B$, hematologic toxicity, and neurologic events. ${ }^{38}$ Additionally, infliximab has black-box warnings for 
Formulary Review of 2 New Biologic Agents: Tocilizumab for Rheumatoid Arthritis and Ustekinumab for Plaque Psoriasis

TABLE 5 Cost of Autoimmune Biologics Available in 2010

\begin{tabular}{|c|c|c|c|c|}
\hline Drug & Maintenance Dosing in RA & $\operatorname{Cost}^{\mathrm{a}}$ in RA & Maintenance Dosing in Psoriasis & Cost $^{\mathrm{a}}$ in Psoriasis \\
\hline $\begin{array}{l}\text { Adalimumab } \\
\text { (Humira) }\end{array}$ & $40 \mathrm{mg}$ every other week & $\begin{array}{l}\$ 959.19 \text { per } 40 \text { mg injection or } \\
\$ 1,918 \text { monthly }\end{array}$ & $40 \mathrm{mg}$ every other week & $\begin{array}{l}\$ 959.19 \text { per } 40 \text { mg injection } \\
\text { or } \$ 1,918 \text { monthly }\end{array}$ \\
\hline $\begin{array}{l}\text { Etanercept } \\
\text { (Enbrel) }\end{array}$ & 50 mg weekly & $\begin{array}{l}\$ 498.71 \text { per } 50 \text { mg injection or } \\
\$ 1,995 \text { monthly }\end{array}$ & 50 mg weekly & $\begin{array}{l}\$ 498.71 \text { per } 50 \mathrm{mg} \text { injection } \\
\text { or } \$ 1,995 \text { monthly }\end{array}$ \\
\hline $\begin{array}{l}\text { Infliximab } \\
\text { (Remicade) }\end{array}$ & $\begin{array}{l}\text { 3-10 mg per kg every } 8 \\
\text { weeks; maximum dose } 10 \\
\text { mg per kg every } 4 \text { weeks }\end{array}$ & $\begin{array}{l}\text { Cost for a } 70 \mathrm{~kg} \text { person ranges } \\
\text { from } \$ 2,367 \text { every } 8 \text { weeks }(\$ 1,184 \\
\text { monthly) to } \$ 5,523 \text { every } 4 \text { weeks }{ }^{b}\end{array}$ & $5 \mathrm{mg}$ per kg every 8 weeks & $\begin{array}{l}\text { Cost for a } 70 \mathrm{~kg} \text { person is } \\
\$ 3,156 \text { every } 8 \text { weeks }(\$ 1,578 \\
\text { monthly) }\end{array}$ \\
\hline $\begin{array}{l}\text { Certolizumab } \\
\text { (Cimzia) }\end{array}$ & 200 mg every other week & $\begin{array}{l}\$ 1,841 \text { per } 200 \text { mg kit ( } 2 \text { injections; } \\
\text { 1-month supply) }\end{array}$ & NA & NA \\
\hline $\begin{array}{l}\text { Alefacept } \\
\text { (Amevive) }\end{array}$ & $\mathrm{NA}$ & $\mathrm{NA}$ & $15 \mathrm{mg}$ weekly for 12 weeks $^{\mathrm{c}}$ & $\begin{array}{l}\$ 1,190 \text { per } 15 \mathrm{mg} \text { injection or } \\
\$ 4,760 \text { monthly for } 3 \text { months }\end{array}$ \\
\hline $\begin{array}{l}\text { Anakinra } \\
\text { (Kineret) }\end{array}$ & 100 mg daily & $\begin{array}{l}\$ 92.24 \text { per } 100 \text { mg injection or } \\
\$ 2,767 \text { monthly }\end{array}$ & NA & NA \\
\hline $\begin{array}{l}\text { Abatacept } \\
\text { (Orencia) }\end{array}$ & 500-1,000 mg every 4 weeks & $\begin{array}{l}\$ 609.24 \text { per } 250 \mathrm{mg} \text { vial (cost per } \\
\text { month ranges from } \$ 1,218 \text { to } \$ 2,437 \text { ) }\end{array}$ & NA & NA \\
\hline $\begin{array}{l}\text { Rituximab } \\
\text { (Rituxan) }\end{array}$ & $\begin{array}{l}2 \times 1,000 \text { mg infusions every } \\
24 \text { weeks }\end{array}$ & $\begin{array}{l}\$ 3,404.50 \text { per } 500 \mathrm{mg} \text { vial or } \\
\$ 13,620 \text { per infusion or } \$ 2,270 \\
\text { monthly }\end{array}$ & NA & $\mathrm{NA}$ \\
\hline $\begin{array}{l}\text { Golimumab } \\
\text { (Simponi) }\end{array}$ & $50 \mathrm{mg}$ every 4 weeks & $\begin{array}{l}\$ 1,982.62 \text { per } 50 \text { mg injections } \\
\text { monthly }\end{array}$ & NA & $\mathrm{NA}$ \\
\hline $\begin{array}{l}\text { Ustekinumab } \\
\text { (Stelara) }\end{array}$ & NA & NA & 45 or 90 mg every 12 weeks ${ }^{d}$ & $\begin{array}{l}\$ 5,595.60 \text { per } 45 \mathrm{mg} \text { or } 90 \mathrm{mg} \\
\text { injection or } \$ 1,865 \text { monthlye }\end{array}$ \\
\hline $\begin{array}{l}\text { Tocilizumab } \\
\text { (Actemra) }\end{array}$ & $\begin{array}{l}4 \text { or } 8 \mathrm{mg} \text { per kg every } 4 \\
\text { weeks }\end{array}$ & $\begin{array}{l}\text { Cost for a } 70 \mathrm{~kg} \text { person ranges from } \\
\$ 1,114 \text { to } \$ 2,229 \text { per month }\end{array}$ & NA & NA \\
\hline
\end{tabular}

${ }^{a}$ For the autoimmune biologics available in the U.S. market as of May 2010. Cost is derived from the AWP in April $2010^{55}$ and the maintenance dosing regimen shown in the table. The monthly cost estimates assume that a 4-week period is 1 month, and actual cost will also vary depending on discounts.

${ }^{b}$ Cost approximation assumes an AWP of $\$ 789$ per $100 \mathrm{mg}$ vial and wasting of remaining vial after use.

'Regimen may be repeated for 1 more 12-week course at least 12 weeks after the initial course.

dU.S. Food and Drug Administration dosing is $45 \mathrm{mg}$ for patients up to $100 \mathrm{~kg}$ body weight and $90 \mathrm{mg}$ for patients over $100 \mathrm{~kg}$ body weight.

eUstekinumab is dosed at weeks 0 and 4 and then every 12 weeks thereafter. AWP cost for first month of therapy (doses 0 and 4 weeks) would be \$11,192, no cost in month 2 , and \$5,596 in month 3 and every 12 weeks thereafter. Annual cost in the first year will be based on 6 doses and will therefore be higher than in subsequent years at approximately 4 doses per year.

fThe tocilizumab starting dose is $4 \mathrm{mg}$ per $\mathrm{kg}$ every 4 weeks, "followed by an increase to $8 \mathrm{mg}$ per $\mathrm{kg}$ based on clinical response" according to the product label. Actual cost depends on body weight and will vary from $\$ 1,114$ at $4 \mathrm{mg}$ per $\mathrm{kg}$ or $\$ 2,229$ at $8 \mathrm{mg}$ per $\mathrm{kg}$ for a $70 \mathrm{~kg}$ person. Cost is estimated using an AWP of $\$ 79.60$ per milliliter for the $20 \mathrm{mg}$ per milliliter vial. Actual costs may be higher as vials are only available in $80 \mathrm{mg}, 200 \mathrm{mg}$, and $400 \mathrm{mg}$ strengths and wastage may occur.

$A W P=$ average wholesale price; $\mathrm{kg}=$ kilogram; $\mathrm{mg}=$ milligram; $\mathrm{NA}=$ not applicable; $\mathrm{RA}=$ rheumatoid arthritis.

increased risk of serious infections and for lymphoma and other malignancies in children and adolescents. ${ }^{38}$ Tocilizumab and ustekinumab have unique mechanisms of action, and the effects of widespread, long-term use are unknown at this time. Tocilizumab's effects on neutrophils, platelets, and lipid levels are unique and concerning amongst the autoimmune biologics, and the long-term implications are unknown. The FDA, in a review of ustekinumab, stated that patients had not been followed for a sufficient period of time, and that the risk of malignancy should be communicated to prescribers. ${ }^{34}$ Extended studies are needed to better define and understand the safety risks of both drugs.

The ACCEPT trial introduces phase 3, comparative data to the autoimmune biologics for the first time and presents a challenge for health care professionals on defining the place in therapy of ustekinumab. ${ }^{20}$ Clinicians and patients may defend ustekinumab as a first-line option due to superior efficacy to etanercept and comparable short-term safety. However, the data are limited to 1 single-blind (investigator) trial in 903 patients. ${ }^{18}$ The TNF antagonists have the advantage in years of experience and a well-defined safety and efficacy profile. Clinicians may continue using the established TNF antagonists first, reserving ustekinumab for patients failing these therapies. Regardless, the phase 3 comparative trial data provide valuable information to decision makers trying to evaluate the clinical advantages between autoimmune biologics. For tocilizumab, the RADIATE trial and FDA indication for tocilizumab place this treatment firmly after TNF antagonist failure..$^{17,28}$

Autoimmune biologics address different components of the autoinflammatory disease process and frequently gain FDA indications in multiple conditions. Ustekinumab $63 \mathrm{mg}$ at weeks 0 and 4 was compared with placebo in the treatment of psoriatic arthritis $(n=146)$. At week 12, an ACR 20 score was achieved by $42 \%$ and $14 \%$ of patients in the ustekinumab 
and placebo groups, respectively $(P<0.001) .{ }^{39}$ Tocilizumab was compared with placebo in a double-blind, withdrawal study in juvenile idiopathic arthritis (JIA) $(n=56){ }^{40}$ At the end of the withdrawal period, $80 \%$ and $17 \%$ of patients treated with tocilizumab $8 \mathrm{mg}$ per $\mathrm{kg}$ and placebo, respectively, maintained an ACR $20 .^{40}$ According to clinicaltrials.gov, ustekinumab is being studied in psoriatic arthritis and Crohn's disease, and tocilizumab has trials ongoing or recruiting in JIA and RA. ${ }^{41,42}$ Clinicians and managed care decision makers should be prepared for additional data and expanded uses of both agents.

Biologic autoimmune agents used to treat RA and psoriasis are expensive, ranging from $\$ 25,000-\$ 50,000$ per year of therapy. According to Prime Therapeutics' commercial book of business prescription medication trend data on arthritis and skin agents, which encompass the autoimmune biologics, the annual growth rate in per member per month (PMPM) cost for this category was 21.1\% from 2007 Q1 through 2009 Q4 (Figure 3). ${ }^{43}$ Growth was driven by an average annual utilization growth rate of $9.2 \%$ and an average annual price inflation rate of $9.0 \%{ }^{43}$

Available information on the price of ustekinumab and tocilizumab indicate comparable pricing between these therapies and existing autoimmune biologics (Table 5). However, administration fees, monitoring, and dose changes make an overall cost comparison difficult. Ustekinumab has higher cost at the initiation of therapy because doses are administered at weeks 0 and 4, for a combined average wholesale price (AWP) drug cost at the current (2010) price of $\$ 11,912$ in the first 30 days, or $\$ 16,788$ at 16 weeks. The first-year ustekinumab AWP cost is $\$ 33,576$ for 6 doses, but the cost in subsequent years with dosing every 12 weeks or 4 times per year would be approximately $\$ 22,384$. The cost of tocilizumab depends on body weight and is dosed consistently every 4 weeks. Tocilizumab AWP cost for a $70 \mathrm{~kg}$ person is $\$ 1,114$ at the dose of $4 \mathrm{mg}$ per $\mathrm{kg}$ or $\$ 2,229$ at $8 \mathrm{mg}$ per $\mathrm{kg}$ or an annual cost that ranges from $\$ 13,368$ to $\$ 26,748$ if dosed 12 times per year. Managed care decision makers are challenged to find a balance in providing access to new autoimmune biologicals for those who need them while encouraging the preferred use of proven cost-effective agents with long-term safety records.

Utilization management programs requiring trial and failure of conventional agents prior to the use of autoimmune biologics is one strategy. A conventional DMARD-first strategy is supported by an analysis by Finckh et al. (2009) showing that conventional DMARD treatment in very early RA is cost effective. ${ }^{44}$ The analysis also found that autoimmune biologics are not cost effective as first-line therapy and should be reserved for patients failing conventional DMARDs. ${ }^{44}$ Selecting preferred autoimmune biologics that cover the majority of indications and requiring trial and failure prior to other biologics is another option. Price variability between vendors should be minimized by using a limited distribution channel and restricting dis- pensing of autoimmune biologics to the specified specialty pharmacy. Health plans may also elect to place autoimmune biologics in a specialty tier with additional cost sharing for the member. However, our research reported previously suggests that patient copayments greater than $\$ 100$ per month for TNF blockers were associated with prescription abandonment. ${ }^{45}$

\section{Conclusions}

Ustekinumab and tocilizumab are the first biologics to inhibit IL-12/23 and IL-6, respectively. The publication of a comparative trial and treatment in patients failing multiple TNF antagonists would better define the value introduced by ustekinumab and tocilizumab. Long-term safety data are needed to understand how different mechanisms of action modify the safety profile compared with the TNF agents. Additional studies will better define the safety risks and establish the place in therapy for these agents. Cost continues to be a problem for the class of biologicals. Managed care decision makers should use all available tools including utilization management programs, benefit design, and restricted distribution networks to provide the most cost-effective pharmacy benefit management for patients and drug plan sponsors.

\section{Authors}

JEREMY A. SCHAFER, PharmD, is Manager of Formulary Development; and NICOLE K. KJESBO, PharmD, BCPS, is Senior Clinical Pharmacist, Prime Therapeutics LLC, Eagan, Minnesota. PATRICK P. GLEASON, PharmD, BCPS, FCCP, is Director of Clinical Outcomes Assessment, Prime Therapeutics LLC, Eagan, Minnesota, and Adjunct Associate Professor, College of Pharmacy, University of Minnesota, Minneapolis, Minnesota.

AUTHOR CORRESPONDENCE: Jeremy A. Schafer, PharmD, Manager of Formulary Development, Prime Therapeutics, 1305 Corporate Center Dr., Eagan, MN 55121. Tel.: 612.777.5097; 612.777.5143; E-mail: jschafer@primetherapeutics.com.

\section{DISCLOSURES}

There was no external funding for this manuscript. The authors are employees of Prime Therapeutics, a pharmacy benefits management company whose ownership includes health plans. This manuscript was written primarily from information that was prepared for and presented to a pharmacy and therapeutics committee.

Schafer was primarily responsible for the concept and design with assistance of the other 2 authors. Schafer collected the data with assistance from Kjesbo, and Schafer interpreted the data with the assistance of the other 2 authors. Schafer wrote the manuscript with the assistance of the other 2 authors, and Schafer and Gleason revised the manuscript. 


\section{REFERENCES}

1. Helmick CG, Felson DT, Lawrence RC, et al. Estimates of the prevalence of arthritis and other rheumatic conditions in the United States. Part I. Arth Rheum. 2008;58(1):15-25.

2. Pugner KM, Scott DI, Holmes JW, Hieke K. The costs of rheumatoid arthritis: an international long-term view. Semin Arthritis Rheum. 2000;29(5):305-20.

3. Joyce AT, Smith P, Khandker R, Melin JM, Singh A. Hidden cost of rheumatoid arthritis (RA): estimating cost of comorbid cardiovascular disease and depression among patients with RA. J Rheumatol. 2009;36(4):743-52.

4. Clarke A, Zowall H, Levinton C, et al. Direct and indirect medical costs incurred by Canadian patients with rheumatoid arthritis: a 12 year study. $J$ Rheumatol. 1997;24(6):1051-60.

5. Sany J, Dropsy R, Daures JP. Cross-sectional epidemiological survey of rheumatoid arthritis patients seen in private practice in France: descriptive results (1629 cases). Rev Rhum Engl Ed. 1998;65(7-9):462-70.

6. Feldman S, Clark A. Psoriasis. Med Clin of N Amer. 1998;82(5):1135-44.

7. Stern RS, Nijsten T, Feldman SR, Margolis DJ, Rolstad T. Psoriasis is common, carries a substantial burden even when not extensive, and is associated with widespread treatment dissatisfaction. J Investig Dermatol Symp Proc. 2004;9(2):136-39.

8. Simpson GL, Yelverton CB, Rittenberg S, Feldman SR. Do utilization management controls for phototherapy increase the prescription of biologics? J Dermatolog Treat. 2006;17(6):359-61.

9. Fowler JF, Duh MS, Rovba L, et al. The impact of psoriasis on health care costs and patient work loss. J Am Acad Dermatol. 2008;59(5):772-80

10. Saag KG, Teng GG, Patkar NM, et al. American College of Rheumatology 2008 recommendations for the use of nonbiologic and biologic diseasemodifying antirheumatic drugs in rheumatoid arthritis. Arthritis Rheum. 2008;59(6):762-84. Available at: http://www3.interscience.wiley.com/cgi-bin/ fulltext/119635887/PDFSTART. Accessed June 8, 2010.

11. National Institute for Health and Clinical Excellence. Adalimumab, etanercept and infliximab for the treatment of rheumatoid arthritis. NICE technology appraisal guidance 130. October 2007. Available at: http://www.nice. org.uk/nicemedia/live/11867/37914/37914.pdf. Accessed June 8, 2010.

12. Menter A, Gottlieb A, Feldman SR, et al. Guidelines of care for the management of psoriasis and psoriatic arthritis: Section 1. Overview of psoriasis and guidelines of care for the treatment of psoriasis with biologics. J Am Acad Dermatol. 2008;58(5):826-50.

13. Hyrich KL, Lunt M, Watson KD, Symmons DP, Silman AJ, Furstenberg CT. Outcomes after switching from one anti-tumor necrosis factor alpha agent to a second anti-tumor necrosis factor alpha agent in patients with rheumatoid arthritis: results from a large UK national cohort study. Arthritis Rheum. 2007;56(1):13-20.

14. Rubbert-Roth A, Finckh A. Treatment options in patients with rheumatoid arthritis failing initial TNF inhibitor therapy: a critical review. Arthritis Res Ther. 2009;11(Suppl 1):1. Available at: http://www.ncbi.nlm.nih.gov/pmc/ articles/PMC2669237/pdf/ar2666.pdf. Accessed June 8, 2010.

15. Agency for Healthcare Research and Quality. Comparative effectiveness of drug therapy for rheumatoid arthritis and psoriatic arthritis in adults. No.11. November 19, 2007. Available at: http://www.effectivehealthcare. ahrq.gov/ehc/products/14/70/RheumArthritisExecSum.pdf. Accessed June 8,2010 .

16. Stelara (ustekinumab). Centocor Ortho Biotech Inc. December 30, 2009. Available at: http://www.accessdata.fda.gov/drugsatfda_docs/ label/2009/125261s001lbl.pdf. Accessed June 8, 2010.

17. Actemra (tocilizumab) for intravenous infusion. Genentech. January 2010. Available at: http://www.gene.com/gene/products/information/actemra/pdf/pi.pdf. Accessed June 8, 2010
18. U.S. Food and Drug Administration. Press release. FDA approves new drug to treat psoriasis. September 25, 2009. Available at: http://www.fda. gov/NewsEvents/Newsroom/PressAnnouncements/2009/ucm183851.htm. Accessed June 8, 2010.

19. U.S. Food and Drug Administration. Press release. FDA approves new drug for rheumatoid arthritis. January 11, 2010. Available at: http://www. fda.gov/NewsEvents/Newsroom/PressAnnouncements/ucm197108.htm. Accessed June 8, 2010.

20. Griffiths CE, Strober BE, van de Kerkhof P, et al., for the ACCEPT Study Group. Comparison of ustekinumab and etanercept for moderate-to-severe psoriasis. N Engl J Med. 2010;362(2):118-28.

21. Bartlett BL, Moody MN, Tyring SK. IL-12/IL-23 inhibitors: the advantage and disadvantages of this novel approach for the treatment of psoriasis. Skin Therapy Lett. 2008;13(8):1-4.

22. U.S. Food and Drug Administration. Center for Drug Evaluation and Research. Pharmacology review of ustekinumab. Application number 125261. Available at: http://www.accessdata.fda.gov/drugsatfda_docs/ nda/2009/125261s000_PharmR.pdf. Accessed June 8, 2010.

23. Lipsky PE. Interleukin-6 and rheumatic diseases. Arthritis Res Ther. 2006;8(Suppl 2):S4.

24. Nakahara H, Nishimoto N. Anti-interleukin-6 receptor antibody therapy in rheumatic diseases. Endocr Metab Immune Disord Drug Targets. 2006;6(4):373-81

25. Leonardi CL, Kimball AB, Papp KA, et al., for the PHOENIX 1 study investigators. Efficacy and safety of ustekinumab, a human interleukin-12/23 monoclonal antibody, in patients with psoriasis: 76 week results from a randomised, double blind, placebo-controlled trial (PHOENIX 1). Lancet. 2008;371(9625):1665-74

26. Papp KA, Langley RG, Lebwohl M, et al., for the PHOENIX 2 study investigators. Efficacy and safety of ustekinumab, a human interleukin-12/23 monoclonal antibody, in patients with psoriasis: 52 -week results from a randomised, double-blind, placebo-controlled trial (PHOENIX 2). Lancet. 2008;371(9625):6175-84

27. Langley RG, Feldman SR, Han C, et al. Ustekinumab significantly improves symptoms of anxiety, depression, and skin-related quality of life in patients with moderate to severe psoriasis: results from a randomized, double-blind, placebo-controlled phase III trial. J Am Acad Dermatol. 2010; May 10. Epub ahead of print

28. Emery P, Keystone E, Tony HP, et al. IL-6 receptor inhibition with tocilizumab improves treatment outcomes in patients with rheumatoid arthritis refractory to anti-tumour necrosis factor biologicals: results from a 24-week multicenter randomised placebo-controlled trial. Ann Rheum Dis. 2008;67(11):1516-23

29. Smolen JS, Beaulieu A, Roth AR, et al., for the OPTION investigators. Effect of interleukin-6 receptor inhibition with tocilizumab in patients with rheumatoid arthritis (OPTION study): a double-blind, placebo-controlled, randomised trial. Lancet. 2008;371(9617):987-97.

30. Maini RN, Taylor PC, Szechinski J, et al. Double-blind randomized controlled clinical trial of the interleukin-6 receptor antagonist, tocilizumab, in European patients with rheumatoid arthritis who had an incomplete response to methotrexate. Arthritis Rheum. 2006;54(9):2817-29.

31. Genovese MC, McKay JD, Nasonov EL, et al. Interleukin- 6 receptor inhibition with tocilizumab reduces disease activity in rheumatoid arthritis with inadequate response to disease-modifying antirheumatic drugs: the tocilizumab in combination with traditional disease-modifying antirheumatic drug thereapy study. Arthritis Rheum. 2008;58(10):2968-80. Available at: http://www3.interscience.wiley.com/cgi-bin/fulltext/121425897/PDFSTART. Accessed June 8, 2010

32. Nishimoto N, Hashimoto J, Miyasaka N, et al. Study of active controlled monotherapy used for rheumatoid arthritis, an IL-6 inhibitor (SAMURAI): evidence of clinical and radiographic benefit from an $\mathrm{x}$ ray reader-blinded randomised controlled trial of tocilizumab. Ann Rheum Dis. 2007;66(1):116267. 
33. Jones G, Sebba A, Gu J, et al. Comparison of tocilizumab monotherapy versus methotrexate monotherapy in patients with moderate to severe rheumatoid arthritis: the AMBITION study. Ann Rheum Dis. 2010;69(1):88-96.

34. U.S. Food and Drug Administration. Center for Drug Evaluation and Research. Medical review of ustekinumab. Application number 125261. Available at: http://www.accessdata.fda.gov/drugsatfda_docs/ nda/2009/125261s000_MedR.pdf. Accessed June 8, 2010

35. Patel RV, Clark LN, Lebwohl M, Weinberg JM. Treatments for psoriasis and the risk of malignancy. J Am Acad Dermatol. 2009;60(6):1001-17.

36. Nishimoto N, Miyasaka N, Yamamoto K, Kawai S, Takeuchi T, Azuma J. Long-term safety and efficacy of tocilizumab, an anti-IL-6 receptor monoclonal antibody, in monotherapy, in patients with rheumatoid arthritis (the STREAM study): evidence of safety and efficacy in a 5-year extension study. Ann Rheum Dis. 2009;68(10):1580-84. Available at: http://ard.bmj.com/content/68/10/1580.full.pdf. Accessed June 8, 2010.

37. Remicade (infliximab). Centocor Ortho Biotech Inc. August 1998. Available at: http://www.accessdata.fda.gov/drugsatfda_docs/label/1998/inflcen082498lb.pdf. Accessed March 30, 2010.

38. Remicade (infliximab). Centocor Ortho Biotech Inc. November 2009. Available at: http://www.remicade.com/remicade/assets/HCP_PPI.pdf. Accessed June 8, 2010.

39. Gottlieb A, Menter A, Mendelsohn A, et al. Ustekinumab, a human interleukin 12/23 monoclonal antibody, for psoriatic arthritis: randomised, double-blind, placebo-controlled, cross-over trial. Lancet. 2009;373(9664):63340.

40. Yokota S, Imagawa T, Mori M, et al. Efficacy and safety of tocilizumab in patients with systemic-onset juvenile idiopathic arthritis: a randomized, double-blind, placebo-controlled, withdrawal phase III trial. Lancet. 2008;371(9617):998-1006.

41. Clinicaltrials.gov. Search for ustekinumab. Available at: http://www.clinicaltrials.gov/ct2/results?term=ustekinumab. Accessed June 8, 2010.

42. Clinicaltrials.gov. Search for tocilizumab. Available at: http://www.clinicaltrials.gov/ct2/results?term=tocilizumab. Accessed June 8, 2010.

43. Prime Therapeutics internal data. Data on file. Costs are reported as total paid per member per month including all actual paid costs (ingredient cost, dispensing, and taxes) by the insurance plan and the member.
44. Finckh A, Bansback N, Marra CA, et al. Treatment of very early rheumatoid arthritis with symptomatic therapy, disease-modifying antirheumatic drugs, or biologic agents: a cost-effective analysis. Ann Intern Med. 2009;151(9):612-21. Available at: http://www.annals.org/content/151/9/612. full.pdf+html. Accessed June 8, 2010.

45. Gleason PP, Starner CI, Gunderson BW, Schafer JA, Sarran HS. Association of prescription abandonment with cost share for high-cost specialty pharmacy medications. J Manag Care Pharm. 2009;15(8):648-58. Available at: http://www.amcp.org/data/jmcp/648-658.pdf

46. Enbrel (etanercept). Wyeth. November 2009. Available at: http://www. enbrel.com/documents/ENBREL-Prescribing-Information.pdf. Accessed June 8, 2010.

47. Humira (adalimumab). Abbott. November 2009. Available at: http:// www.rxabbott.com/pdf/humira.pdf. Accessed June 8, 2010.

48. Cimzia (certolizumab). UCB Inc. November 2009. Available at: http:// www.cimzia.com/pdf/Prescribing_Information.pdf. Accessed June 8, 2010

49. Amevive (alefacept). Astellas Pharma US Inc. March 2009. Available at: http://www.accessdata.fda.gov/drugsatfda_docs/label/2009/125036sl00lbl. pdf. Accessed June 8, 2010.

50. Kineret (anakinra). Amgen April 2004. Available at: http://www.accessdata.fda.gov/drugsatfda_docs/label/2004/103950s5039lbl.pdf. Accessed June 8, 2010.

51. Rituxan (rituximab). Genentech. February 2010. Available at: http:// www.accessdata.fda.gov/drugsatfda_docs/label/2010/103705s5311lbl.pdf. Accessed June 8, 2010.

52. Simponi (golimumab). Centocor Ortho Biotech Inc. November 2009. Available at: http://www.simponi.com/Prescribing-Information/PrescribingInformation.pdf. Accessed June 8, 2010.

53. Orencia (abatacept). Bristol Myers Squibb. August 2009. Available at: http://www.accessdata.fda.gov/drugsatfda_docs/label/2009/125118s0086lbl. pdf. Accessed June 8, 2010.

54. Iwakura Y, Ishigame H. The IL-23/IL-17 axis in inflammation. J Clin Invest. 2006;116(5):1218-22. Available at: http://www.jci.org/articles/ view/28508. Accessed June 8, 2010

55. Wolters Kluwer Health. Medi-Span database. Accessed April 12, 2010. 